\title{
Modelling natural regeneration of European beech in Saxony, Germany: identifying factors influencing the occurrence and density of regeneration
}

\author{
Maximilian Axer $^{1}\left[\right.$ D $\cdot$ Sven Martens ${ }^{2} \cdot$ Robert Schlicht $^{3} \cdot$ Sven Wagner ${ }^{1}$
}

Received: 29 June 2020 / Revised: 19 March 2021 / Accepted: 8 April 2021 / Published online: 16 April 2021

(C) The Author(s) 2021

\begin{abstract}
The potential utilisation of natural regeneration of European beech (Fagus sylvatica L.) for forest conversion has received little attention to date. Ecological knowledge is necessary to understand and predict successful natural regeneration of beech. The objective of this study was to improve understanding of what drives the occurrence of beech regeneration and, once regeneration is present, what drives its density. In the study, we utilised a forest inventory dataset provided by Sachsenforst, the state forestry service of Saxony, Germany. The dataset was derived from 8725 permanent plots. Zero-altered negative binomial models (ZANB) with spatial random effects were used to analyse factors influencing occurrence and density simultaneously. The results provided by the spatial ZANB models revealed that the probability of the occurrence of beech regeneration is highly dependent on seed availability, i.e. dependent on source trees in close proximity to a plot. The probability of beech regeneration rises with the increasing diameter of a potential seed tree and decreases with increasing distance to the nearest potential seed source. The occurrence of regeneration is affected by overstorey composition and competition exerted by spruce regeneration. Where sites are affected by groundwater or temporary waterlogging, the impact on the occurrence of regeneration is negative. Although distance to the nearest potential seed source has an influence on occurrence, this variable exerts no influence on density. A high regeneration density arises in conjunction with a high beech basal area in the overstorey. Beech regeneration density, but not occurrence, is negatively affected by browsing intensity. These variables can be used to predict the occurrence and density of beech regeneration in space to a high level of precision. The established statistical tool can be used for decision-making when planning forest conversion using natural regeneration.
\end{abstract}

Keywords European beech $\cdot$ Established natural regeneration $\cdot$ INLA $\cdot$ Zero-altered negative binomial model $\cdot$ Spatial random effects · Bayesian inference

\section{Introduction}

European beech (Fagus sylvatica L.) is the most abundant broadleaf tree species in central Europe. Due to its high shade tolerance and very broad ecological amplitude, beech

Communicated by Derek Sattler.

Maximilian Axer

maximilian.axer@tu-dresden.de

Sven Martens

sven.martens@smul.sachsen.de

Robert Schlicht

robert.schlicht@tu-dresden.de

Sven Wagner

sven.wagner@tu-dresden.de dominates the potential natural vegetation on many sites and plays a key role as a late successional species (Ellenberg and Leuschner 2010).

Natural regeneration can play an important role in the process of converting pure coniferous stands to mixed stands by increasing the proportion of broadleaf trees (Felton et al. 2016), contributing to the restoration of forests. The

1 Chair of Silviculture, Institute of Silviculture and Forest Protection, TU Dresden, 01737 Tharandt, Germany

2 Department of Forest Management, Forest Inventory and Forest Valuation, State Forest Enterprise Sachsenforst, 01796 Pirna, Germany

3 Chair of Forest Biometrics and Forest Systems Analysis, Institute of Forest Growth and Forest Computer Sciences, TU Dresden, 01737 Tharandt, Germany 
regeneration phase is the best opportunity to influence tree species composition and forest ecosystem structures (Fischer et al. 2016; Löf et al. 2018). With natural regeneration playing an expanding role in silviculture in central Europe, the monitoring of the success of regeneration in stands is an important issue for forest management. However, predicting natural regeneration in mixed stands is difficult (Löf et al. 2018).

To better understand and predict successful natural regeneration of beech, a sound knowledge of the key ecological processes is required. Successful regeneration encompasses numerous ecological processes such as flowering, seed production, seed dispersal, storage, germination, seedling development and the successful establishment of juvenile trees (Harper 2010; Wagner et al. 2010; Fischer et al. 2016).

The process of flowering and the total number of seeds depends on the trees' physiological age and the onset of maturity (Owens and Blake 1985). Within stands, beech begins seed production between the ages of 50 and 80 (Brown 1953). Wagner (1999) established a relationship between seed production and tree diameter. Beech masts irregularly, at intervals of three to ten years (Övergaard et al. 2007). The distance to the parent tree is relevant to seed dispersal by means of barochory and to the resulting seed density (Sagnard et al. 2007). While barochory commonly results in beech nut dispersal up to a radius of $20 \mathrm{~m}$ (Wagner 1999; Kutter and Gratzer 2006; Millerón et al. 2013), zoochorus dispersal is dependent on the suitability of the stands as a habitat for seed-dispersing animals (Löf et al. 2018). Kunstler et al. (2007) found beech regeneration in pine stands up to $3000 \mathrm{~m}$ from the nearest mature beech stand. In temperate latitudes, plants usually bridge the unfavourable growth conditions of the winter months by means of dormancy (Runkle 1989). This is usually associated with the storage of diaspores on the forest floor. There, the diaspores are susceptible to harmful fungi, predation and unfavourable environmental conditions (Jensen 1985; Madsen 1995).

After successful germination, establishment and early growth, beech seedling development is dependent upon light, soil moisture, nutrient supply and browsing intensity (Minotta and Pinzauti 1996). Madsen and Larsen (1997) identified light availability to be the most important factor influencing sapling density. Beech seedlings can establish under a wide range of light conditions (Emborg 1998). However, the survival rate and growth of beech seedlings increase with increasing irradiation (Madsen 1994; Minotta and Pinzauti 1996). The overstorey (Paluch et al. 2019), the shrub layer and the herbaceous vegetation all reduce the resources available to beech seedlings. Ground vegetation affects seedling growth especially severely when grasses dominate the field layer (Coll et al. 2003, 2004; Lin et al. 2014). In addition to interactions prompted by ground vegetation and the overstorey, there are effects of competition between the regeneration of various tree species. Dobrovolny (2016) demonstrated an increase in the Norway spruce (Picea abies L.) density with increasing irradiation and a superior height growth in comparison with beech from a light intensity of $20 \%$ or more. Furthermore, seedling density can be reduced by browsing. Beech seedlings can be browsed by birds, rodents, deer and other herbivores (Madsen 1995; Olesen and Madsen 2008).

The aim of this study was to develop a statistical model to predict natural regeneration of beech. A statistical analysis will show important variables influencing natural regeneration. Using the variables, the occurrence of natural regeneration can be predicted. This is of great interest for regeneration ecology as well as for practical forestry, as nature-oriented forest management favours natural regeneration in terms of cost reduction and site adapted regeneration, especially as a means to facilitate adaptation to climate change (Zerbe 2002; Dobrowolska 2006; Finkeldey and Hattemer 2010; Milad et al. 2013; Vrška et al. 2016; Kaliszewski 2017; Polley et al. 2018). There are several approaches for regeneration modelling, from which two groups can be distinguished: statistical models and mechanistic (process) models. While mechanistic models predict regeneration as a system of biological processes (Nathan and Muller-Landau 2000), statistical models allow for an accurate reproduction of observed patterns. Within statistical modelling, regeneration can be modelled on different spatial scales. While the first phases of the regeneration process are often investigated by modelling the dispersal curve through maximum likelihood methods (Ribbens et al. 1994; Clark et al. 1999) and point process statistics (Wild et al. 2014) on a small scale, regeneration establishment models use wide-scale routine inventory data. Regeneration establishment models are models that deal exclusively with the establishment phase of regeneration. The probability of the occurrence and the density of natural regeneration of beech can be analysed and predicted using regeneration establishment models.

Studies on regeneration establishment models for beech are rare (Klopčič et al. 2015; Kolo et al. 2017). Many studies have tended to focus on the ingrowth of beech, including recruitment over a certain threshold value, e.g. $\mathrm{dbh}>10$ or $12 \mathrm{~cm}$ (Klopcic et al. 2012; Manso et al. 2019; Zell et al. 2019). For the purposes of this paper, established regeneration was defined as beech trees with a height greater than $20 \mathrm{~cm}$ and a diameter at breast height (dbh) smaller than $7 \mathrm{~cm}$. In addition to different spatial scales, established regeneration can also be analysed on different time scales. Established regeneration can be quantified either as a regeneration density over a measurement threshold at a defined moment in time or as a regeneration rate, i.e. the number of trees reaching a threshold value over a certain period of time (Lexerod and Eid 2005). The former approach is preferable for silvicultural planning, because a certain regeneration 
density is important for management seeking to achieve a high quality stand in the future.

A special feature of forest inventory data based on grid samples with permanent plots is the small experimental area of the sample plot. Most investigations include only plot information when modelling regeneration density ( $\mathrm{Li}$ et al. 2011; Zhang et al. 2012; Shen and Nelson 2018). As a consequence, spatial patterns of seed availability resulting from the plot environment are considered in few studies (Shive et al. 2018; Monteiro-Henriques and Fernandes 2018). In addition to the crucial issue of small plot size, inventory datasets contain spatial autocorrelation due to abiotic or biotic processes and spatial structures in unobserved explanatory variables (Bachl et al. 2019). Few regeneration establishment models have considered spatial correlation (Dobrowski et al. 2015).

To the best of our knowledge, there have been no approaches to the modelling of beech regeneration taking spatial dependence into account. We applied a new approach to a statistical establishment model using the example of natural beech regeneration in the lowland forests of Saxony, Germany. The objective of this study was to improve understanding of what drives the absence or occurrence of beech regeneration and, once regeneration is present, what drives its density, by testing a wide collection of explanatory variables. Six hypotheses were derived from the knowledge presented above: (1) based on beech nut dispersal, it was hypothesised that the probability of the occurrence of regeneration and the density increase with an increase in the plot-specific basal area of beech and that there is a decrease with increasing distance between the plot and the nearest mature beech stand. (2) It was expected that the probability of beech regeneration increases with beech diameter, as seed production is related to tree diameter. (3) Due to the reduced availability of resources such as water and light as a function of the overstorey, it was assumed that beech regeneration density is affected by the total basal area of the overstorey of the plot. (4) In addition to the properties of the overstorey, it was hypothesised that due to interspecific competition in the understorey, beech regeneration density will decrease with an increasing density of spruce regeneration. (5) Beech regeneration density is negatively affected by herbivory, as a result of increased mortality. (6) Furthermore, it was assumed that the occurrence and density of beech regeneration are affected by the soil characteristics of the site. An excess of water is expected to affect the occurrence of beech regeneration negatively.

\section{Materials and methods}

\section{Study area}

The study was conducted in state forest located in northern Saxony, Germany. The region is characterised by Pleistocene lowlands and their transitions to loess uplands. The region encompasses eight 'growth districts' (forstliche Wuchsgebiete, Gauer and Aldinger 2005) (Table 1). Figure 1 visualises the geographic range of this study area. Scots pine is the predominant tree species in both mixed forests and pure stands (Table 1). Climate records (1981-2010) indicate mean annual precipitation of between 534 and $796 \mathrm{~mm}$, and the elevation ranges from 0 to $600 \mathrm{~m}$ above sea level (Gauer and Kroiher 2012).

Table 1 Distribution of permanent sampling points (PSP) in the growth areas and characterisation of the growth areas in terms of tree species composition, altitude, average annual temperature (Temp.) and mean annual precipitation (Precip.) (Gauer and Kroiher 2012)

\begin{tabular}{|c|c|c|c|c|c|c|c|c|}
\hline Growth district & Number of PSP & $\begin{array}{l}\text { Beech } \\
\text { share } \\
(\%)\end{array}$ & Oak share $(\%)$ & $\begin{array}{l}\text { Spruce } \\
\text { share } \\
(\%)\end{array}$ & Pine share $(\%)$ & Altitude (m) & Temp. $\left({ }^{\circ} \mathrm{C}\right)$ & Precip $(\mathrm{mm})$ \\
\hline $\begin{array}{l}\text { Sächsisch-Thüringisches Löß- } \\
\text { Hügelland }\end{array}$ & 60 & 3 & 26 & 16 & 14 & $150-450$ & 8.6 & 631 \\
\hline $\begin{array}{l}\text { Sachsen-Anhaltinische Löß- } \\
\text { Ebene }\end{array}$ & 4 & 1 & 13 & 1 & 4 & $75-300$ & 9.1 & 504 \\
\hline $\begin{array}{l}\text { Mittleres nordostdeutsches } \\
\text { Altmoränenland }\end{array}$ & 276 & 1 & 9 & 1 & 74 & $75-300$ & 8.9 & 534 \\
\hline $\begin{array}{l}\text { Düben-Niederlausitzer Alt- } \\
\text { moränenland }\end{array}$ & 6487 & 1 & 4 & 2 & 83 & $0-300$ & 8.9 & 597 \\
\hline Lausitzer Löß-Hügelland & 174 & 2 & 8 & 28 & 39 & $0-600$ & 8.2 & 700 \\
\hline Oberlausitzer Bergland & 7 & 4 & 3 & 75 & 6 & $300-600$ & 7.7 & 796 \\
\hline $\begin{array}{l}\text { Westlausitzer Platte und } \\
\text { Elbtalzone }\end{array}$ & 1716 & 5 & 12 & 19 & 45 & $150-450$ & 8.8 & 652 \\
\hline Leipziger Sandlöß-Ebene & 1 & 1 & 13 & 1 & 15 & $150-300$ & 9.1 & 569 \\
\hline
\end{tabular}


Fig. 1 Location of the study region in northern Saxony, Germany, and the permanent sampling plot inventory. Dots represent the coordinates of the sample plots. Representation of the triangulation with 7752 vertices used for the SPDE basis function representation of the Matérn Gaussian field. Section representing the southern part of the study area

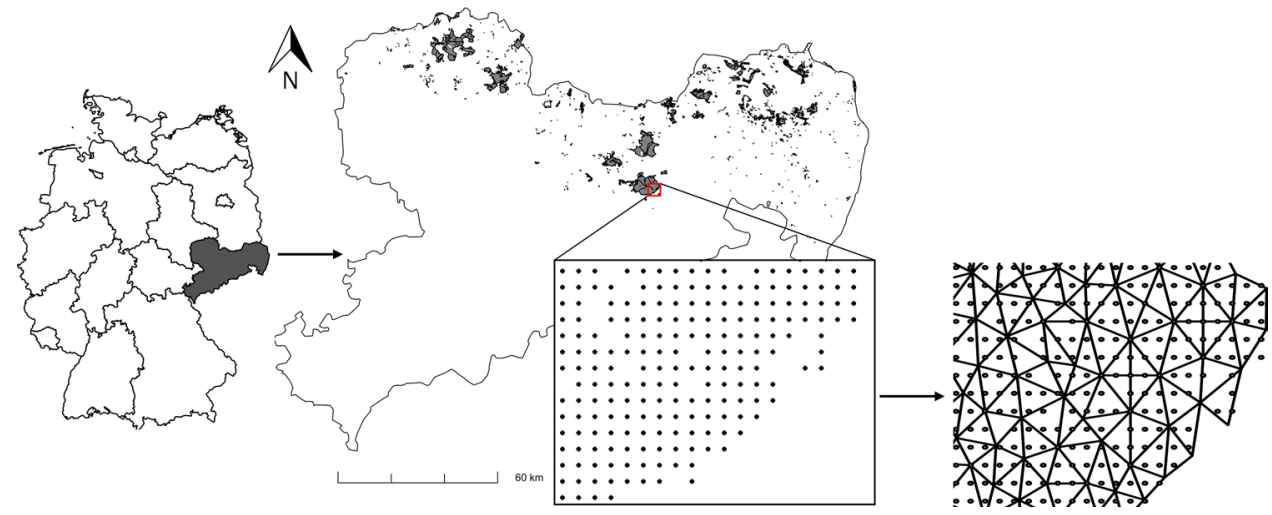

\section{Forest inventory and analysis of data}

The data used in the study were generated in the context of a forest inventory and were provided by the Saxony state forestry service (Sachsenforst). The forest inventory surveyed 8725 permanent sample plots on a grid square with a $200 \mathrm{~m}$ side length (see also Fig. 1). Each plot consisted of three concentric circles with a 6 and $12 \mathrm{~m}$ radius. In the $6 \mathrm{~m}$ circle, all trees with a dbh $\geq 7 \mathrm{~cm}$ and $<30 \mathrm{~cm}$ were measured, while in the largest circle only trees with a $\mathrm{dbh} \geq 30 \mathrm{~cm}$ were recorded. In each plot, the location of all trees above the measurement threshold relative to the plot centre was recorded, based on distance and azimuth. In addition, tree species, dbh, age and several height parameters were measured and recorded.

For each plot, a subplot with a $2 \mathrm{~m}$ radius $(\approx 12.57$ $\mathrm{m}^{2}$ ), located $5 \mathrm{~m}$ north of the plot centre, was established. Within each subplot, regeneration of height $\geq 20 \mathrm{~cm}$ and a dbh $<7 \mathrm{~cm}$ was measured. The inventory design distinguished between tree height/dbh classes for the regeneration. The first size class $B 0$ included regeneration of height $\geq 20 \mathrm{~cm}$ and $<50 \mathrm{~cm}$. The second size class $B 1$ included regeneration of height between $50 \mathrm{~cm}$ and $<130 \mathrm{~cm}$, whereas the third size class $B 2$ consisted of trees of height $\geq 130 \mathrm{~cm}$. The number of individuals was recorded separately according to tree species, size class, browsing damage and whether protected from browsing damage. A distinction was also made between natural and artificial regeneration. The maximum number of seedlings recorded was 15; that is, a theoretical distribution of numbers was truncated at 15 .

We used the number of naturally regenerated beech seedlings in the plot as the dependent variable for every size class, because it was to be expected that regeneration would be influenced differently by variables within regeneration development classes (Žemaitis et al. 2019). The occurrence and density of beech regeneration were assumed to be affected by various variables (see Table 2 and hypotheses).

All computations were done using $\mathrm{R}$ version 3.4.1 ( $\mathrm{R}$ Core Team 2018). The following explanatory variables characterised the overstorey of the plot: quadratic mean diameter of beech in the overstorey $\left(1.3 \mathrm{~m}, D_{\mathrm{q}}\right)$, stand basal area (BA)

Table 2 Summary statistics of the median values and ranges in parentheses for the explanatory variables in the model fit for plots without beech regeneration, beech regeneration size class $B 0$, beech regeneration size class $B 1$ and beech regeneration size class $B 2$

\begin{tabular}{|c|c|c|c|c|c|c|}
\hline Variable & Acronym & Units & Without beech & Beech $B 0$ & Beech $B 1$ & Beech $B 2$ \\
\hline Quadratic mean diameter beech & $D_{\mathrm{q}}$ & $\mathrm{cm}$ & $0(0-113.2)$ & $18.72(0-140.9)$ & $10.5(0-140.9)$ & $10.1(0-114)$ \\
\hline Upscaled basal area of a plot & BA & $\mathrm{m}^{2} / \mathrm{ha}$ & $28.61(0-85.5)$ & $28.61(0-69.4)$ & $29.4(0-66.5)$ & $29.6(0-66)$ \\
\hline Basal area beech & BA_B & $\mathrm{m}^{2} / \mathrm{ha}$ & $0(0-52.8)$ & $4.2(0-60.6)$ & $1.8(0-50.1)$ & $1.8(0-50.1)$ \\
\hline Basal area spruce & BA_S & $\mathrm{m}^{2} / \mathrm{ha}$ & $0(0-81)$ & $0(0-43.5)$ & $0(0-38.1)$ & $0(0-41)$ \\
\hline Basal area pine & BA_P & $\mathrm{m}^{2} / \mathrm{ha}$ & $20.1(0-74.8)$ & $9.2(0-56.1)$ & $12.2(0-60.1)$ & $13.2(0-55)$ \\
\hline Distance mature beech stand $($ age $>80)$ & D80 & $\mathrm{m}$ & $628.7(0-24,045)$ & $114(0-2743)$ & $116(0-6719)$ & $115(0-8353)$ \\
\hline Buffer beech stand, area $100 \mathrm{~m}$ stand $($ age $>80)$ & BUF100 & ha & $0(0-22.8)$ & $0(0-30.9)$ & $0(0-30.9)$ & $0(0-30.9)$ \\
\hline Buffer beech stand, area $500 \mathrm{~m}$ stand $($ age $>80)$ & BUF500 & ha & $0(0-40.6)$ & $2.6(0-40.6)$ & $2.7(0-41)$ & $2.3(0-41)$ \\
\hline Spruce seedling density B1 & Spr_no_B1 & $\mathrm{n}$ & $0(0-16)$ & $0(0-15)$ & $0(0-8)$ & $0(0-15)$ \\
\hline Spruce seedling density B2 & Spr_no_B2 & $\mathrm{n}$ & $0(0-15)$ & $0(0-4)$ & $0(0-6)$ & $0(0-12)$ \\
\hline Browsing percent & $\mathrm{BP}$ & $\%$ & $55(0-100)$ & $52(0-100)$ & $47.5(0-100)$ & $41.8(0-100)$ \\
\hline Humus thickness & HT & $\mathrm{t} / \mathrm{ha}$ & $104(4-378)$ & $135(4-342)$ & $137.5(4-311)$ & $145(4-343)$ \\
\hline
\end{tabular}


and species-specific basal area are determined on the basis of each plot. The total basal area for the plot and the species-specific basal area were scaled up to hectare level. The understorey was described by explanatory variables. To test the influence of established spruce regeneration on beech regeneration, the density in the plot of spruce of size class $B 1$ and size class $B 2$ was used (Spr_no_B1, Spr_no_B2).

In addition to the plot-specific explanatory variables, the following variables from the plot surroundings were included. In order to estimate seed availability across the study area, the shortest distance from each sampling point to the nearest potential seed source (mature beech stand or stand with admixed beech trees older than 80 years) $D 80$ was determined using the gDistance function in R's rgeos package (Bivand and Rundel 2019). Another proxy variable to estimate seed availability was buffer. Within three different neighbourhoods (BUF100, BUF250 and BUF500), the proportion of the area occupied by beech stands ( $>80$ years) was estimated using the gBuffer function in R's rgeos package (Bivand and Rundel 2019). For both variables, beech stands $>80$ years were chosen in order to examine the established regeneration, which may have established several decades ago (B2). The age criterion ensures that the surrounding beech stands had already produced seed at some point in the past. The location of the beech stands was recorded in the context of the stand inventory and provided as a spatial polygons data frame.

Russell et al. (2017) showed that it is essential to consider the impact of browsing when modelling regeneration. The influence of browsing was characterised by two variables. First, browsing percentage $(B P)$ was defined as the ratio between the number of browsed and the total number of rowan (Sorbus aucuparia L.) within size classes $B 0$ and $B 1$. The ratio of browsed rowan seedlings was used as the species is widely distributed in the study area and preferentially browsed by deer (Motta 2003; Götmark et al. 2005). The size classes were chosen based on the size of the game species. Rowan regeneration of size classes $B 0$ and $B 1$ occurred in 2100 of the 8725 examined plots. Inventory plots without rowan regeneration were set as not available (NA). Based on the 2100 plots, the browsing impact was interpolated for all plots using inverse distance weighting in R's gstat package (Gräler et al. 2016). Second, a factor variable characterising the browsing intensity in a plot was defined. The study distinguished between non-browsed, simply browsed and multiply browsed rowan, depending on the frequency of browsing on a single plant. The highest browsing intensity reported was assigned to the plot as a factor. If there was no rowan regeneration in the plot, this was assigned to the category absence of rowan. A binary variable was used to indicate whether a plot was fenced in to prevent damage caused by game.
Elevation, aspect, the nutrient content of the soil and its moisture level were provided by Sachsenforst as site condition variables. The factor variable was divided into four factor levels according to the moisture level. A distinction was made between well-drained, temporarily waterlogged and groundwater-affected sites. Where no level of water storage capacity was provided for the site, the fourth factor level 'not available' was used. In order to analyse the influence of humus layer on beech regeneration, the nitrogen and carbon content and the total thickness of the humus layer were provided. These data were derived from a regionalised soil inventory. All variables describing climate conditions were retrieved from GIS databases provided by Gauer and Kroiher (2012).

\section{Data pre-treatments}

In order to avoid errors, the data were tested for their suitability in terms of model building (Zuur et al. 2018). Data exploration was carried out following the protocol described in Zuur et al. (2010). Outliers, which were checked with Cleveland dotplots, were not found. In order to select the correct distribution function for modelling, the data were examined for zero inflation. Frequency plots were built for this purpose, to show the number of observations with a certain count of beech seedlings. In addition, a variance inflation factor (vif) was calculated for every covariate in order to detect multicollinearity. Collinearity is defined as the existence of correlation between covariates (Zuur et al. 2010). Here, the function corvif was used (Zuur et al. 2009). The threshold value was set at 3 and covariates with higher vifs were dropped. Subsequent to variable selection, we searched for relationships between the explanatory variables and the response variable by deploying multipanel scatterplots. Finally, the data were examined for dependency structures. Due to a small proportion of seed-bearing beech in Saxony (see also Table 1) and its limited seed dispersal and patchy establishment, local density is likely to be autocorrelated (Flores et al. 2009). This kind of clustering of regeneration has the potential to lead to zero inflation, especially when a regular inventory grid is used. Spatial correlation can also result from unobserved explanatory variables (Bachl et al. 2019).

\section{Estimating seedling density}

Due to the nature of the regeneration process, regeneration data often follow a zero-inflated and overdispersed count distribution (Zhang et al. 2012; Shen and Nelson 2018). The observed count of beech seedlings in the Saxonian forest inventory also revealed a very high proportion of zeros (Fig. 2). Different methodological approaches have been used for regeneration and recruitment modelling, in order 
to account for this special feature of the data. In previous studies, density was often modelled in a two-step approach. First, the probability of occurrence is modelled based on a set of covariates. Second, another equation estimates the density of regeneration based on the same or a different set of covariates (Vanclay 1992; Sterba et al. 1997; Qin 1998; Klopcic et al. 2012; Yang and Huang 2015). Recent papers used a one-step modelling approach by combining two separate estimation processes into a joint distribution of probabilities (Shive et al. 2018; Shen and Nelson 2018; MonteiroHenriques and Fernandes 2018; Zell et al. 2019). To take into account zero inflation and overdispersion, they made use of zero-inflated distribution models. Zero-inflated Poisson (ZIP), zero-altered Poisson (ZAP), zero-inflated negative binomial (ZINB) and zero-altered negative binomial distributions (ZANB) are distributions commonly used to include excess zeros in the modelling process (Fortin and DeBlois 2007; Li et al. 2011; Zhang et al. 2012). The major advantage of zero-altered models is that both processes (occurrence and density) can be investigated, facilitating ecological understanding (Cunningham and Lindenmayer 2005).

Following the example of Zuur et al. (2018), the model was fitted in a Bayesian framework using integrated nested Laplace approximation (INLA). In general, Bayesian inference for complex spatial models can be implemented with simulation methods such as the Markov chain Monte Carlo method (MCMC). Compared to MCMC, INLA is advantageous in terms of faster computation due to deterministic and accurate approximation by integrals in contrast to stochastic simulations (Krainski et al. 2019). The package R-INLA (Lindgren and Rue 2015) in R (R Core Team 2018) provides the INLA method to solve complex models with spatial random effects. For zero-inflated models, there is currently no approach within the package R-INLA to model occurrence depending on the covariates (Zuur et al. 2018). Zero-altered negative binomial generalised linear models (ZANB) were used in this study for the first time to model both probability of occurrence $\{0,1\}$ and density of beech seedlings $\left(B D_{i}\right)(i=1, \ldots, n)$ at $n$ observations in the plots, as a function of covariates. The ZANB model simultaneously estimates the parameters of a zero-truncated negative binomial distribution conditional on a Bernoulli trial. The former applies for the count data, whereas the latter deals with absence occurrence. The variable $1_{\left\{B D_{i}>0\right\}}$, which indicates the occurrence (value 1) or absence (value 0 ) of seedlings, is 1 with probability $\pi_{i}$,

$\operatorname{Pr}\left(B D_{i}=0\right)=1-\pi_{\mathrm{i}}, \quad 0 \leq \pi \leq 1$

and conditionally, provided seedlings are present, $B D_{i}$ has the truncated negative binomial distribution given by
$\operatorname{Pr}\left(B D_{i}=x \mid B D_{i}>0\right) \propto \frac{k+x-1}{x} \cdots \frac{k}{1}\left(\frac{\mu_{i}}{k+\mu_{i}}\right)^{x}$ for $x=1,2, \ldots$

The parameters $\pi_{\mathrm{i}}$ and $\mu_{i}$ in both parts are expanded as a function of different covariates. Except for the explicitly hierarchical dependencies, all variables are assumed to be independent.

First, a base or 'initial model' taking no account of spatial dependence was used. This model used only covariates as predictors of occurrence and density. To examine whether patterns of spatial correlation could be used as surrogates for unobserved explanatory variables, we added a spatial random structure to the base model, i.e. a 'complex model'. We then compared the complex model to the initial model to determine whether the spatial component could contribute to explaining the variation in beech regeneration occurrence and density. In addition, a model consisting of only a spatial component was tested, i.e. 'spatial random model'. This procedure was also applied to a unimodal Poisson, negative binomial and zero-altered Poisson model. Preliminary investigations showed that the complex ZANB model exhibited the best fit to the data (shown in "Optimal random structure" section). The following formula describes the full ZANB model used to test the variables:

$B D_{i} \sim \operatorname{ZANB}\left(\mu_{i}, \pi_{i}, k\right)$

$E\left(B D_{i}\right)=\frac{\pi_{i}}{1-P_{0}} \times \mu_{i} \quad$ where $P_{0}=\left(\frac{k}{\mu_{i}+k}\right)^{k}$

$\operatorname{var}\left(B D_{i}\right)=\frac{\pi_{i}}{1-P_{0}} \times\left(\mu_{i}^{2}+\mu_{i}+\frac{\mu_{i}^{2}}{k}\right)-\left(\frac{\pi_{i}}{1-P_{0}} \times \mu_{i}\right)^{2}$

$\log \left(\mu_{i}\right)=\beta_{0}+x_{1 i} \beta_{1}+\ldots x_{m i} \beta_{m}+u_{i}$

$u=\left(u_{i}\right)_{i=1, \ldots, n} \sim N\left(0, \sum_{u}\right)$

$\operatorname{logit}\left(\pi_{i}\right)=\gamma_{0}+z_{1 i} \gamma_{1}+\ldots+z_{n i} \gamma_{n}+v_{i}$

$v=\left(v_{i}\right)_{i=1, \ldots, n} \sim N\left(0, \sum_{v}\right)$

The term $\pi_{\mathrm{i}}$ is the estimated probability of beech regeneration in the plot, i.e. occurrence, and is modelled via the Bernoulli part of the model. The logit transformation is defined as $\operatorname{logit}\left(\pi_{i}\right)=\log \left(\frac{\pi_{i}}{1-\pi_{i}}\right)$. The $\gamma \mathrm{s}$ correspond to the $n$ coefficients of the binary model, which are multiplied with each of the $n$ selected explanatory variables $z_{i}$. A zero-truncated negative binomial part of the model is used for the 
estimation of nonzero densities $\mu_{\mathrm{i}}$, where $\mu_{\mathrm{i}}$ is log transformed. The $\beta$ s correspond to the $m$ coefficients of the count model, which are multiplied with each of the $m$ selected explanatory variables $\mathrm{x}_{i}$. For the parameter estimation of the fixed effects, the default prior distributions of R-INLA, i.e. normal distributions, were used. $\beta_{0}, \ldots, \beta_{m}$ and $\gamma_{0}, \ldots, \gamma_{n} \sim N(0,1000)$

In addition to the fixed effects, the zero-truncated negative binomial model estimated a hyperparameter $k$ called size, which takes overdispersion into account. The default prior distributions of R-INLA were used for the parameter estimation of $k$, i.e. $\log$ gamma prior distribution (Table A1). Weakly informative prior distributions were selected for the coefficients as a priori knowledge was not available.

The terms $u_{i}$ and $v_{i}$ are random intercepts assumed to be spatially correlated with mean 0 and covariance matrix $\sum$ in the counts and binary parts of the model. It was assumed that $u$ and $v$ exhibit Markovian behaviour and follow a Gaussian Markov random field (GMRF). To quantify the associated covariance matrices of $u$ and $v$, Matérn covariance functions were used and numerically approximated using SPDE (continuous domain stochastic partial differential equation). The SPDE approach provided the Matern covariance parameter, i.e. hyperparameters $\theta_{1}=\log (\tau)$ and $\theta_{2}=\log (\kappa)$. The hyperparameter $\kappa$ quantified the range of the effect as the distance at which the spatial dependency diminishes. The hyperparameter $\tau$ is a measure of the strength of the spatial random effects (Lindgren and Rue 2015). R-INLA uses a normal distribution for the priors of $\theta_{1}$ and $\theta_{2}$ (Table A1).

A dense grid of non-overlapping triangles over the sampling area was needed to solve the SPDE. Therefore, the finite element approach was applied. The boundary of the study area and the locations of the plots were used to build the mesh of non-overlapping triangles using the function inla.mesh. $2 \mathrm{~d}()$. max.edge and cutoff were used as arguments within this function in order to control the shape of the triangles. The maximum edge argument specified the triangles' maximum allowed edge length for the inner and outer part of the mesh and was set to 700 (Zuur et al. 2017). The cutoff argument ensured that there was a minimum allowed distance between two points. This argument was set to 250 . As the coordinate projection was set up in a UTM projection, these values were in metres. In total, there were 7752 vertices covering the study area. Figure 1 shows part of the mesh that was used to approximate the spatial field. Spatial prediction at a specific location within in the GMRF was straightforward because SPDE provided the approximation of the entire spatial process. It was just a matter of including the locations where predictions were required as observations of missing values in the model (Krainski et al. 2019). The works of Lindgren and Rue (2015), Zuur et al. (2017) and Krainski et al. (2019) are recommended for further information on INLA and the SPDE approaches.
As the influence of the explaining variables was expected to vary between the different size classes of beech regeneration (see Table 2), the models were individually fitted for each size class. All 16 chosen variables were tested as predictors in both the count and in the binary part of the model.

The model output could be differentiated in fixed effects and hyperparameters. The posterior mean and the quantiles were presented to summarise the posterior marginal distribution. Analogous to frequentist statistics, a parameter is considered not significant if the $95 \%$ credible interval includes 0 when taking the $2.5 \%$ and $97.5 \%$ quantiles of the posterior distribution. Non-significant variables were removed from the fixed part of the model. The posterior mean indicates the influence of the parameter.

The Watanabe-Akaike information criterion (WAIC) was applied for model selection. WAIC consists of two terms representing the quality of fit and the model complexity. For further details see Gelman et al. (2014). The model with the smallest WAIC was chosen. The leave-one-out crossvalidation served as a further factor for model selection, used to quantify the prediction accuracy of the model. This factor could also be used to validate the model. R-INLA computed the so-called conditional predictive ordinates (CPO). It was defined as the posterior probability of an omitted observation given all the other data for the model fit. Large values indicate a good fit of the model to the observed data. The $\mathrm{CPO}$ values are presented in dotplots, and the mean logarithm CPO (LCPO) was calculated as a measure summarising the values. Lower values of the LCPO indicate a better fit of the model. The model accuracy of the occurrence part of the model was evaluated using receiver operating characteristic (ROC) curves. The ROC curve is generated by plotting the rate of true positive results against the rate of false positive results at different threshold settings. Values at 0.5 indicate a fit that is no better than random. Values of 1 indicate a perfect fit.

\section{Results}

\section{Characteristics of beech regeneration}

As expected, a high number of the inventory plots did not reveal any occurrence of beech natural regeneration (Fig. 2). Approximately $91.5 \%$ of all plots contained no beech regeneration in the $B 0$ size class. On average, 3.9 individuals of size class $B 0$ were found in the 744 colonised plots $(0.31$ ind. $\mathrm{m}^{-2}$ ). Approximately $92.3 \%$ and $93.1 \%$ of all plots contained no beech regeneration of size class $B 1$ or $B 2$, respectively. Beech regeneration of size class $B 1$ was found in 676 plots, and the mean regeneration count per colonised plot was around $2.9\left(0.23\right.$ ind. $\left.\mathrm{m}^{-2}\right)$. Only 601 plots possessed beech regeneration of size class $B 2$. The mean beech count 

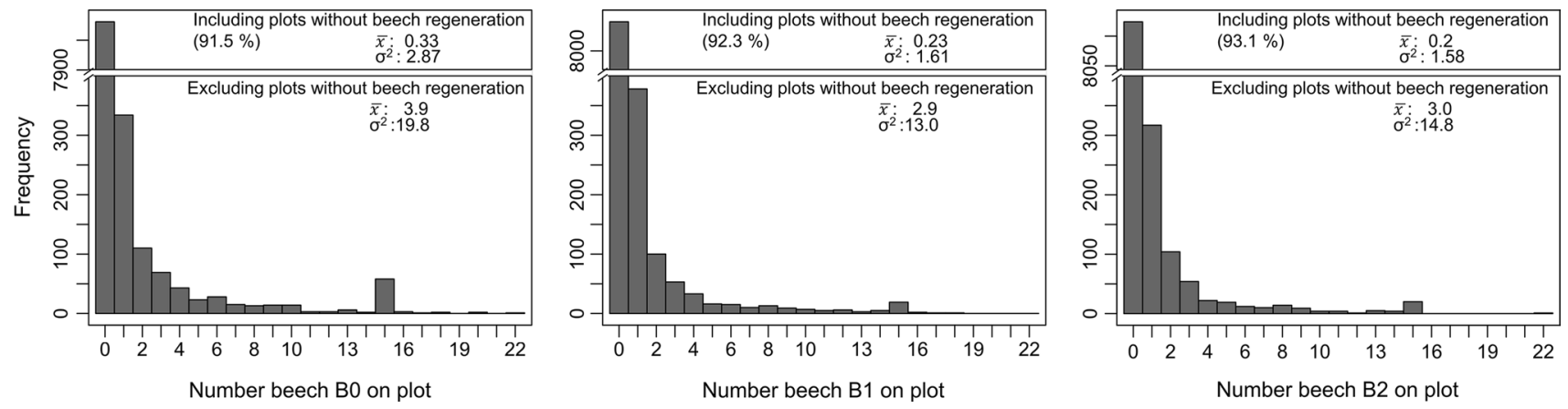

Fig. 2 Histogram with a Y-axis break for the beech regeneration count on the plot for size classes $B 0, B 1$ and $B 2$. The proportion of plots without oak regeneration, the mean $(\bar{x})$ and the variance $\left(\sigma^{2}\right)$ are given

in plots with beech regeneration of size class $B 2$ was around $3.0\left(0.24\right.$ ind. $\left.\mathrm{m}^{-2}\right)$. Analyses revealed that natural beech regeneration included an excessive number of non-occurrence (zeros) and demonstrated a large variation around the mean. A higher count of beech regeneration is observed less frequently than a low count (Fig. 2). In the dataset, a regeneration count of 15 constituted an exception. The smallest size class $(B 0)$ exhibited a higher density in the colonised plots than $B 1$ and $B 2$ (Fig. 2).

\section{Optimal random structure}

Spatial correlation was expected to occur as the data were collected on a systematic grid. A comparative analysis revealed that those models with covariates only, and models with a spatial term only, exhibited higher WAIC values than the full model, suggesting a poorer fit for the former. This result indicated that the spatial relationship between the plots contained valuable information that is not captured by environmental covariates alone. As a result, the final ZANB model contained spatial correlation in the count part as well as in the binary part of the model. For the sake of a simplified presentation, the two classes of effects (fixed effects and spatial random effects) for the occurrence and density of regeneration are described separately in the following. However, it should be mentioned that the ZANB model fits both components simultaneously. All effects presented separately are conditional on the rest of the model.

\section{Occurrence model of beech regeneration}

Many of the covariate data elements originate from the same systematic grid as the regeneration data and other covariates were interpolated from wider grids. Therefore, we expected some collinearity between the different covariates. According to the vif, we found multicollinearity among the buffer queries of different neighbourhoods and between distances to nearest potential seed sources at different ages selected.
Only uncorrelated covariates were used for the following analysis.

Among the three different size classes, different variables had an impact on regeneration occurrence (Table 3). Plotting probabilities of the occurrence of beech regeneration $B 0$ against different $D_{\mathrm{q}}$ at different humus thicknesses revealed a positive influence of $D_{\mathrm{q}}$ and a slightly positive influence of humus layer (Fig. 3). Based on an estimated probability greater than the threshold value of 0.5 , Fig. 3 indicates that beech regeneration was likely to occur from a $D_{\mathrm{q}}$ of $41 \mathrm{~cm}$ and higher. The probability of occurrence increased with increasing $D_{\mathrm{q}}$. Distance to the nearest beech stand had a significant negative impact on the occurrence of beech regeneration. The probability of the occurrence of beech regeneration decreased with increasing distance to the nearest mature beech stand ( $>80$ years). In addition, beech regeneration was found to be more likely as the proportion of the area occupied by beech within the $500 \mathrm{~m}$ radius increased. Figure 3 highlights the effect of the distance to the nearest mature beech stand on different sites. The probability of beech regeneration decreased drastically when the distance to the nearest beech stand became greater than $1000 \mathrm{~m}$. Beech regeneration was very unlikely at yet greater distances, as indicated by an estimated probability of 0.34 . Where distance was equal, the probability of the occurrence of beech regeneration on well-drained sites was greater than on groundwater-affected and temporarily waterlogged sites. Figure 3 also highlights the importance for the occurrence of beech regeneration the influence of spruce regeneration density and spruce basal area. Where there are five spruce seedlings of size class $B 2$ or more on a plot, beech regeneration of size class $B 0$ can no longer be expected to occur. This corresponds to a spruce regeneration density of 4000 per hectare. The probability of beech regeneration occurrence became very low where spruce basal area exceeded $30 \mathrm{~m}^{2} / \mathrm{ha}$.

$D_{\mathrm{q}}$, distance to the nearest mature beech stand, basal area of spruce, humus thickness and excess water showed 
Table 3 Fixed effects of the occurrence/absence part (Bernoulli part) of the ZANB models for size classes $B 0, B 1, B 2$

\begin{tabular}{llrrr}
\hline Model & Covariate & Mean & 0.025 quant & 0.975 quant \\
\hline$B 0$ & Intercept & -2.323 & -2.854 & -1.809 \\
& $D_{\text {q }}$ & 0.050 & 0.045 & 0.055 \\
$D_{80}$ & -0.001 & -0.001 & -0.001 \\
Spr_no_B2 & -0.331 & -0.737 & -0.013 \\
BA_S & -0.023 & -0.041 & -0.007 \\
BA_P & -0.013 & -0.020 & -0.006 \\
HT & 0.003 & 0.001 & 0.005 \\
BUF500 & 0.025 & 0.007 & 0.043 \\
Groundwater-affected & -0.647 & -1.113 & -0.171 \\
Well-drained & -0.072 & -0.075 & 0.347 \\
Temporarily water- & -0.693 & -1.257 & -0.130 \\
logged & & & \\
Intercept & -2.722 & -3.262 & -2.204 \\
$D_{\text {q }}$ & 0.033 & 0.028 & 0.037 \\
$D_{80}$ & -0.001 & -0.002 & -0.001 \\
BA_S & -0.021 & -0.038 & -0.004 \\
HT & 0.003 & 0.001 & 0.005 \\
Groundwater-affected & -0.726 & -1.235 & -0.204 \\
Well-drained & 0.237 & -0.183 & 0.686 \\
Temporarily water- & -0.002 & -0.559 & 0.563 \\
logged & & & \\
Intercept & -2.889 & -3.457 & -2.340 \\
$D_{\text {q }}$ & 0.028 & 0.023 & 0.032 \\
$D_{80}$ & -0.001 & -0.002 & -0.001 \\
HT & 0.004 & 0.002 & 0.006 \\
Groundwater-affected & -0.938 & -1.466 & -0.400 \\
Well-drained & 0.030 & -0.403 & 0.485 \\
Temporarily water- & -0.742 & -1.374 & -0.115 \\
logged & & & \\
\hline
\end{tabular}

The optimised models with the lowest WAIC values are presented. In the table, the output is shown with the posterior mean and the $95 \%$ credible intervals $(0.025$ and 0.975$)$. Interpreting the estimated values, it should be noted that the covariates have quite different ranges

similar effects on the probability of the occurrence of beech of size class $B 1$ as was the case for size class $B 0$ (Table 3 ). While the occurrence of beech regeneration of size class $B 0$ was very likely for a $D_{\mathrm{q}}>41 \mathrm{~cm}$, size class $B 1$ occurred more frequently from $D_{\mathrm{q}}>55 \mathrm{~cm}$, indicated by a probability $\geq 0.5$ (Fig. 3). The probability of occurrence decreased with increasing distance to the nearest mature beech stand. Regeneration was unlikely on well-drained sites from distances $\geq 300 \mathrm{~m}$. Regeneration was also unlikely on groundwater-affected sites, even in the vicinity of mature beech stands, indicated by an estimated probability $<0.5$. The covariates pine basal area and spruce regeneration density did not show any effect on the occurrence of beech of size class $B 1$.
In contrast to size classes $B 0$ and $B 1$, the occurrence of size class $B 2$ was not dependent on spruce and pine basal area. However, $D_{\mathrm{q}}$, distance to the nearest mature beech stand, humus thickness and excess water showed similar effects on the probability of occurrence (Table 3 ). Beech regeneration of size class $B 2$ occurred from $D_{\mathrm{q}} \geq 70 \mathrm{~cm}$ (see Fig. 3). Furthermore, occurrence was only likely in the vicinity of mature beech stands. The model predicted no beech regeneration of size class $B 2$ on groundwater-affected sites, independent of the distance to the nearest mature beech stands, with an estimated probability of 0.2 .

\section{Count model of beech regeneration}

Stand variables significantly influenced the extent of beech regeneration (Table 4), whereas no site variables exhibited an effect on regeneration density. Among the stand variables, beech basal area and $D_{\mathrm{q}}$ had a positive effect on the density of size class $B 0$. Figure 4 shows the effect of beech basal area with a variable $D_{\mathrm{q}}$ on regeneration density. The quadratic term of beech basal area was found to have a negative effect on regeneration density of size class $B 0$. Regeneration density rose sharply with increasing beech basal area, especially for plots $>20 \mathrm{~m}^{2} / \mathrm{ha}$. After reaching the maximum, the regeneration density of size class $\mathrm{B} 0$ decreases as the beech basal area increases. In addition, beech regeneration density is higher with higher $D_{\mathrm{q}}$. A high density of beech regeneration of size class $B 0$ was more likely in plots with non-browsed or simply browsed rowan. Plots with the factor multiply browsed rowan had a significantly lower beech regeneration density than those with only low or no browsing of rowan. The density of beech regeneration decreased with increasing basal areas of pine and spruce. Spruce basal area had a significant negative influence on density. The model predicted a low beech regeneration density for a spruce basal area of $30 \mathrm{~m}^{2} /$ ha (Fig. 4).

Beech basal area, $D_{\mathrm{q}}$ and pine basal area showed similar effects on the density of beech of size class $B 1$ as was the case for size class $B 0$. However, the model did not reveal any effect of spruce basal area on the regeneration density of size class $B 1$. Whereas the factor browsing intensity showed an impact on the regeneration density of size class $B 0$, the browsing percent had a significant negative effect for size class $B 1$. Figure 4 highlights the effect of $D_{\mathrm{q}}$ and browsing percent on the regeneration density of size class $B 1$. Beech regeneration density was found to be higher for plots with a low browsing percent in rowan. The regeneration density of size class $B 1$ was lower than that of size class $B 0$. The maximum predicted regeneration density was 11 seedlings per plot, corresponding to a density of 8750 seedlings per hectare (Fig. 6).

Beech basal area and $D_{\mathrm{q}}$ had similar effects on regeneration density for size class $B 2$ as for size classes $B 0$ and $B 1$. 


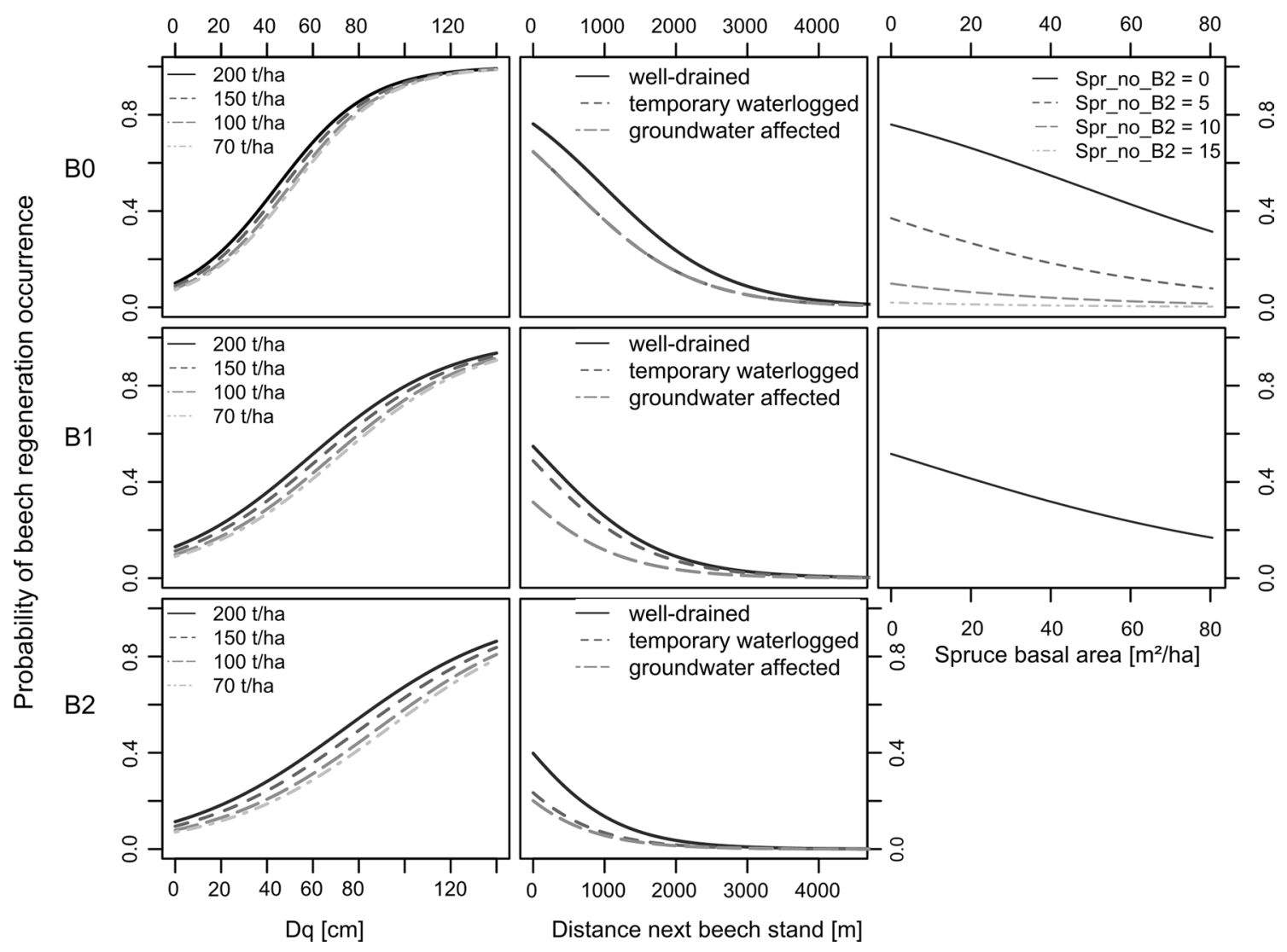

Fig. 3 Predicted probability of the occurrence of natural regeneration of beech depending on $D_{\mathrm{q}}$ and humus thickness (left), distance to the nearest mature beech stand on different sites (middle) and spruce basal area with varying numbers of spruce seedlings $B 2$ (right) for

In contrast to the effects they had on size classes $B 0$ and $B 1$, spruce and pine basal area had no significant effect on size class B2. The total basal area in a plot did influence density negatively, however (Fig. 4). Similar to the effects it had on size class $B 1$, browsing percent in rowan had a negative impact on regeneration density. The predicted density for size class $B 2$ was even lower than for size classes $B 0$ and $B 1$ at a medium beech basal area (Fig. 4).

\section{Spatially smooth random effect}

In addition to the fixed effects, the model included spatial random effects. The mesh used to fit the data is presented in Fig. 1. The spatial random field was defined by the hyperparameters $\theta_{1}$ and $\theta_{2}$. Table $\mathrm{A} 2$ (Appendix) shows the values of the hyperparameters that defined the spatial range and variance of the random field. In order to visualise the spatial random effects, an example area within the study area was selected. It is a representative large closed forest area used to explain the spatial random effects, which were estimated.

Figure 5 shows the example area of the spatial random field for the binary part of the model, Fig. 6 for the different size classes (all continuous variables are set to their mean; all factors are set to their most frequent factor level). The confidence intervals were not plotted for reasons of clarity, as they are quite large

zero-truncated count part. The spatial random fields for the Bernoulli part of the models indicate that there was an obvious spatial pattern of unexplained variability in the example area where the probability of beech occurrence could not be precisely predicted by the fixed effects alone. The probability of the occurrence of beech regeneration of size class $B 0$ was higher to the south of the example area in reality than was modelled by the fixed effects. The probability of occurrence was higher especially at the edges of fragmented forest areas, both in the example area (Fig. 5) and in other parts of the study area. For some parts of the north-west of the study area, the probability of regeneration occurrence was also higher than predicted by the fixed effects. Furthermore, there were parts with a high probability of an absence of regeneration. In the case of the example area in Fig. 5, the probability of occurrence was higher in the northern part. In the eastern part of the example area, the probability of occurrence was lower than predicted by the fixed effects. Spatial random effects for the occurrence of beech regeneration for size classes $B 1$ and $B 2$ showed similar but more distinct effects than for size class $B 0$. 
Table 4 Fixed effects of the count part (zero-truncated) of the ZANB models for size classes $B 0, B 1, B 2$

\begin{tabular}{|c|c|c|c|c|}
\hline Model & Covariate & Mean & 0.025 quant & 0.975 quant \\
\hline \multirow[t]{10}{*}{ B0 } & Intercept & -0.141 & -0.458 & 0.156 \\
\hline & BA_B & 0.073 & 0.038 & 0.107 \\
\hline & $\mathrm{I}\left(\mathrm{BA} \mathrm{B}^{\wedge} 2\right)$ & -0.001 & -0.002 & -0.001 \\
\hline & $D_{\mathrm{q}}$ & 0.018 & 0.011 & 0.025 \\
\hline & BA_S & -0.049 & -0.080 & -0.018 \\
\hline & BA_P & -0.016 & -0.026 & -0.005 \\
\hline & BI_without & 0.253 & -0.127 & -0.648 \\
\hline & BI_simple & 0.766 & 0.116 & 1.459 \\
\hline & BI_multiple & -0.452 & -0.835 & -0.066 \\
\hline & Size $k$ & 0.645 & 0.617 & 63.110 \\
\hline \multirow[t]{6}{*}{ B1 } & Intercept & -0.135 & -0.546 & 0.256 \\
\hline & BA_B & 0.023 & 0.004 & 0.043 \\
\hline & $D_{\mathrm{q}}$ & 0.019 & 0.011 & 0.027 \\
\hline & BA_P & -0.02 & -0.032 & -0.008 \\
\hline & $\mathrm{BP}$ & -0.006 & -0.011 & -0.001 \\
\hline & Size $k$ & 0.447 & 0.346 & 0.511 \\
\hline \multirow[t]{6}{*}{ B2 } & Intercept & 0.327 & -0.218 & 0.857 \\
\hline & BA_B & 0.044 & 0.021 & 0.068 \\
\hline & $D_{\mathrm{q}}$ & 0.014 & 0.005 & 0.024 \\
\hline & $\mathrm{BP}$ & -0.009 & -0.015 & -0.004 \\
\hline & BA & -0.023 & -0.036 & -0.010 \\
\hline & Size $k$ & 0.368 & 0.352 & 0.399 \\
\hline
\end{tabular}

The optimised models with the lowest WAIC values are presented. In the table, the output is shown with the posterior mean and the $95 \%$ credible intervals $(0.025$ and 0.975$)$. Interpreting the estimated values, it should be noted that the covariates have quite different ranges

The precision of the prediction of occurrence achieved by the different models is shown both in Fig. 5 and in the ROC curves (Figure A1, Figure A2 and Figure A3). These figures also show how the model prediction is improved by the random effects, as a comparison is presented including and excluding random effects.

The spatial random fields for the zero-truncated count part of the models is shown (Fig. 6), using the same example area referred to above. The figure reveals a pattern of unexplained variability in parts of the example area where beech regeneration density was not predicted precisely by the fixed effects alone. The comparison of the random fields indicated that the random effects were smaller for size class $B 0$ than for $B 1$ and $B 2$. There were some areas for which density was higher than predicted by fixed effects. For the $B 2$ size class model, the $u_{i} s$ were even close to 1.6 , corresponding to a fourfold increase in density due to spatial correlation. Most of these areas were at the edges of the forest complexes and close to villages and the city of Dresden. The observed regeneration density was high in these locations. However, there were some areas exhibiting a density $60 \%$ lower than predicted by the fixed effects. Most of these areas were inside the forest areas (Fig. 6). The precision of the overall prediction provided by the different models can be seen both in Fig. 6 and in the CPO values (Figure A4, Figure A5 and Figure A6). The comparison of observed densities with predicted densities, root mean square error (RMSE) and bias estimate in the form of the mean prediction error (E), as well as the CPO values of the leave-one-out cross-validation indicated good prediction accuracy (Table A3).

\section{Discussion}

\section{Methodological discussion}

In this study, we successfully created complex ZANB spatial models with various covariates stemming from both the plot and the surrounding stand. In contrast to many earlier studies that followed a frequentist approach (Zhang et al. 2012; Klopcic et al. 2012; Yang and Huang 2015; Shen and Nelson 2018; Monteiro-Henriques and Fernandes 2018; Zell et al. 2019), a Bayesian approach was applied. Although maximum likelihood methods and Bayesian methods with weakly informative priors provide the same results for fixed effect models (Rue et al. 2009; Zuur et al. 2018), the great advantage of using Bayesian methods in R-INLA is the userfriendly integration of spatial random effects. The definition of complex variance structures (e.g. Matérn covariance function) is straightforward. The MCMC algorithm (Rathbun and Fei 2006; Flores et al. 2009; Entezari et al. 2019) and the INLA algorithm can be used to estimate the spatial random effects of geostatistical models. However, the computational efficiency of INLA means it exhibits much higher computation speed than MCMC approaches (Rue et al. 2009; Lindgren and Rue 2015). In addition, R-INLA offers a simple way to provide criteria for model comparison and prediction accuracy (Rue et al. 2009).

The ZANB model provides a useful framework for modelling regeneration data with an excess of zeros. It enabled us to examine both processes relevant to occurrence and processes that influence density, and therefore improve our understanding of the regeneration ecology of beech (Welsh et al. 1996; Cunningham and Lindenmayer 2005). The twostep computation described in chapter 2.4. is how Zuur et al. (2018) suggested applying the function inla(), which cannot directly handle unequal probabilities $\pi_{i}$. This was done in one pass by applying the function to a stacked response vector consisting of all $1_{\left\{B D_{i}>0\right\}}, i=1, \ldots, n$, and the nonzero values $B D_{i}$, and approximating the truncated negative binomial distribution for the second part with a zero-altered negative binomial distribution where the probability of zero values is fixed at a number very close to 0 . However, not all probability distributions are currently available for model building in R-INLA. There is no possibility within R-INLA to calculate 


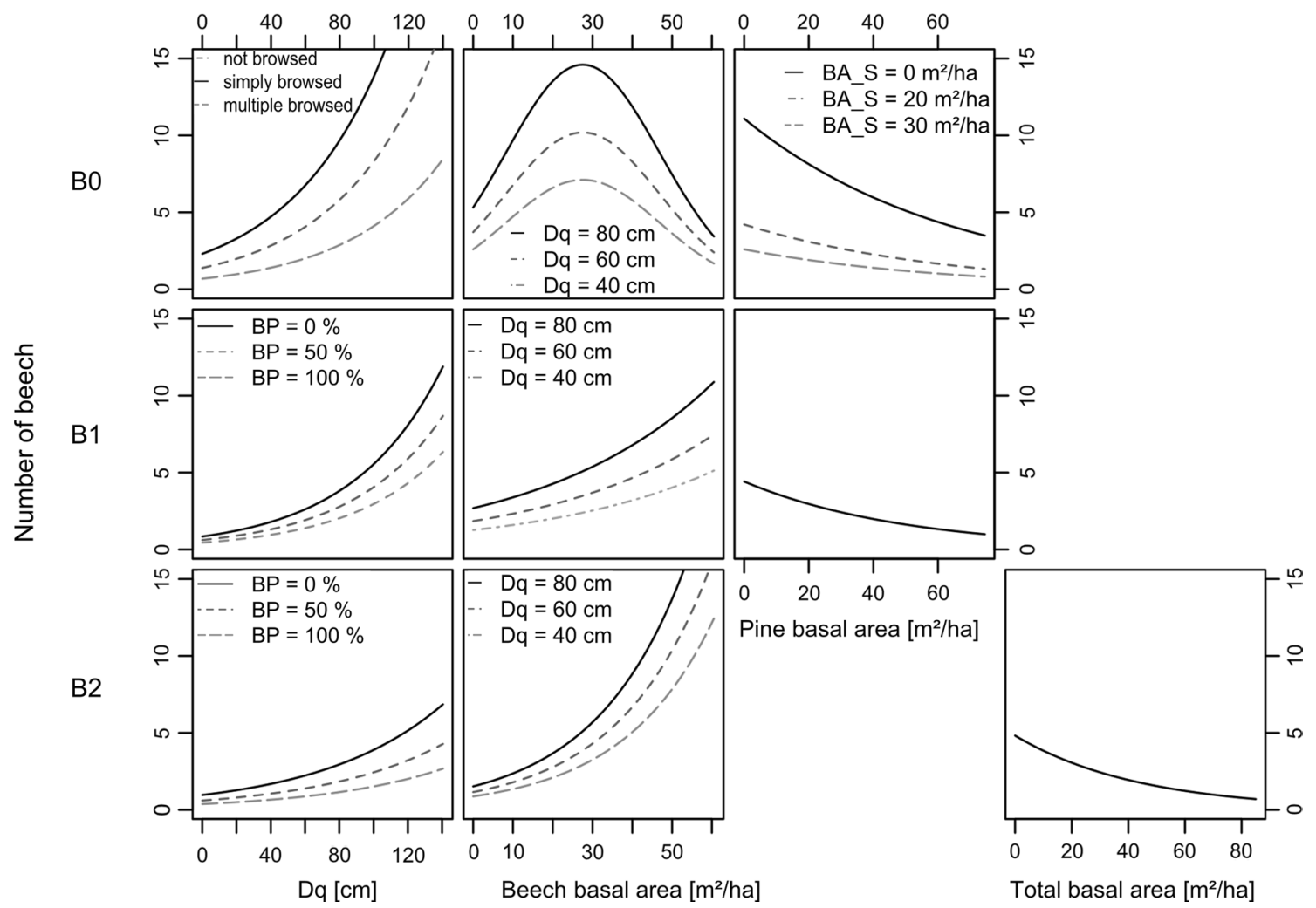

Fig. 4 Predicted density of natural regeneration of beech depending on beech basal area with varying quadratic mean beech dbh (left), beech basal area with browsing intensity and percent in rowan (middle), pine basal area with different spruce basal area (middle) and total basal area for different size classes (all continuous variables are set to their mean; all factors are set to their most frequent factor level). The confidence intervals were not plotted for reasons of clarity, as they are quite large

covariates. In addition, the model can be improved after the next inventory with follow-up data. A major disadvantage of inventory data is the small experimental plot size. As a consequence, the dispersal of beech cannot be depicted by the plot itself. The distance to the nearest mature beech stand is an estimate of seed availability. It is a biased estimator of the effective dispersal distance providing underestimations of the dispersal distance, as has been shown by parentage analysis (Oddou-Muratorio et al. 2011; Millerón et al. 2013). However, dispersal can be overestimated if not all mature beeches have been recorded. The accuracy of the detection of beech stands in the stand inventory is crucial. Further information on this topic can be found in Axer and Wagner (2020).

Inventory data used in regeneration modelling usually have a nested structure and are grouped within geographic locations. In addition, regeneration is a rather uncertain process, as it is affected by successful flowering, masting, storage, germination and establishment. The regeneration data exhibited a high degree of spatial autocorrelation, which should be considered when modelling natural regeneration. Few satisfactory results have been obtained for regeneration establishment models and their predictions in the past 


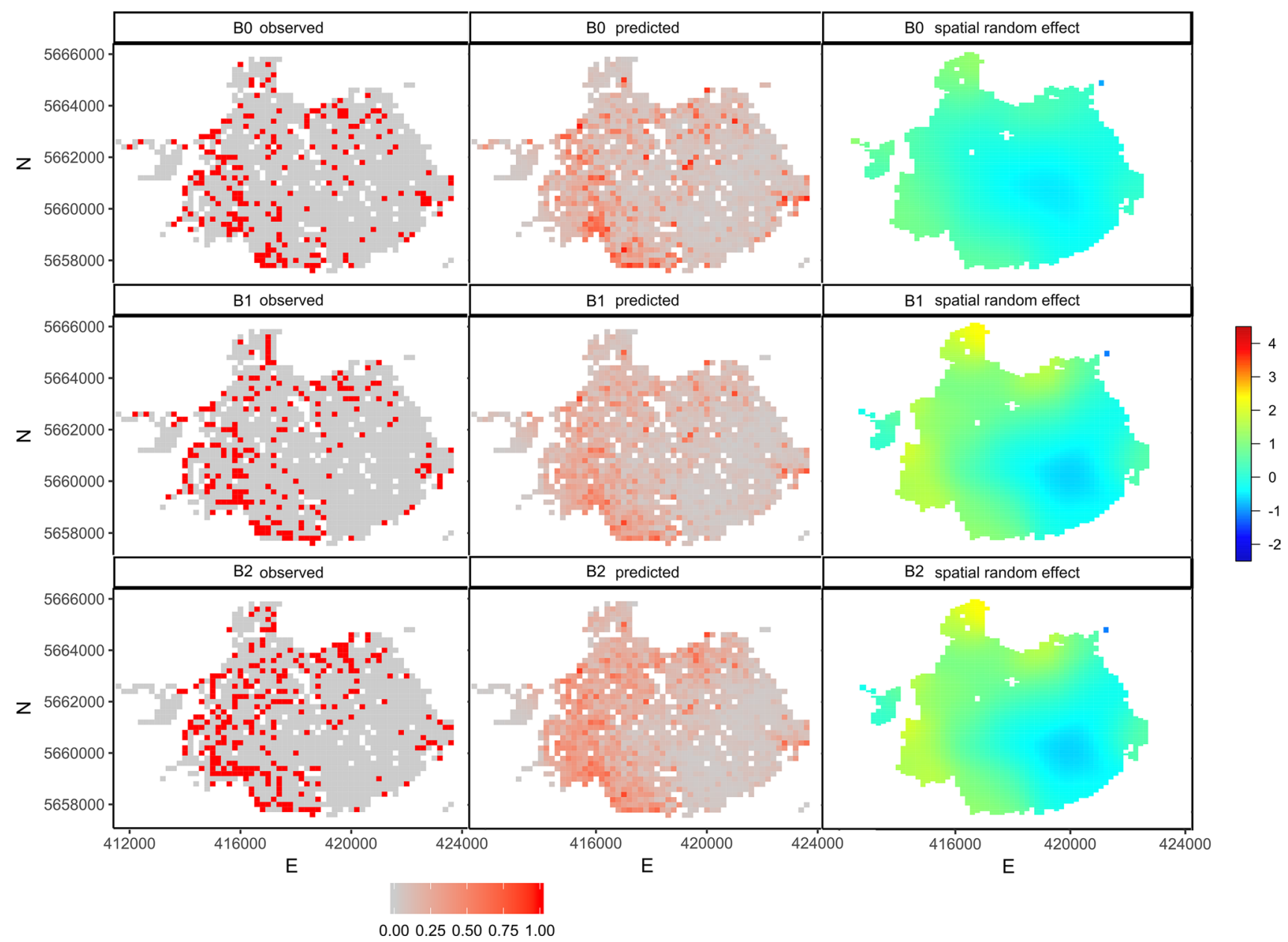

Fig. 5 Example area from within the study region with observed occurrence of beech regeneration (left), spatial prediction of the occurrence of beech regeneration (middle) and spatial random field for the binary part of the ZANB model (right) for the three size classes. Areas shaded dark blue have a lower probability of occurrence of regeneration than that predicted by the fixed effects. Yellow to red areas have a higher probability

regeneration establishment models also, as spatially correlated count data are also present here.

Spatial prediction for a given location is straightforward as the model provides the approximation of the entire Gaussian Markov random field (Lindgren and Rue 2015). The variability is correctly assigned to the predictions and enables predictions at unsampled locations (Beguin et al. 2012). The prediction in INLA can be performed by including locations in the model with missing response values. In this way, maps for the occurrence and density of beech regeneration can be generated easily (Fuglstad and Beguin 2018; Krainski et al. 2019). This is an important planning tool for forest management (Figs. 5, 6). It supports decision-making on how to utilise natural beech regeneration, e.g. for forest conversion.

Established regeneration in inventory plots, that is, trees at least 3-5 years old, may have undergone varying ecological conditions from the time of germination and establishment until the day of inventory. Due to the time lag between 


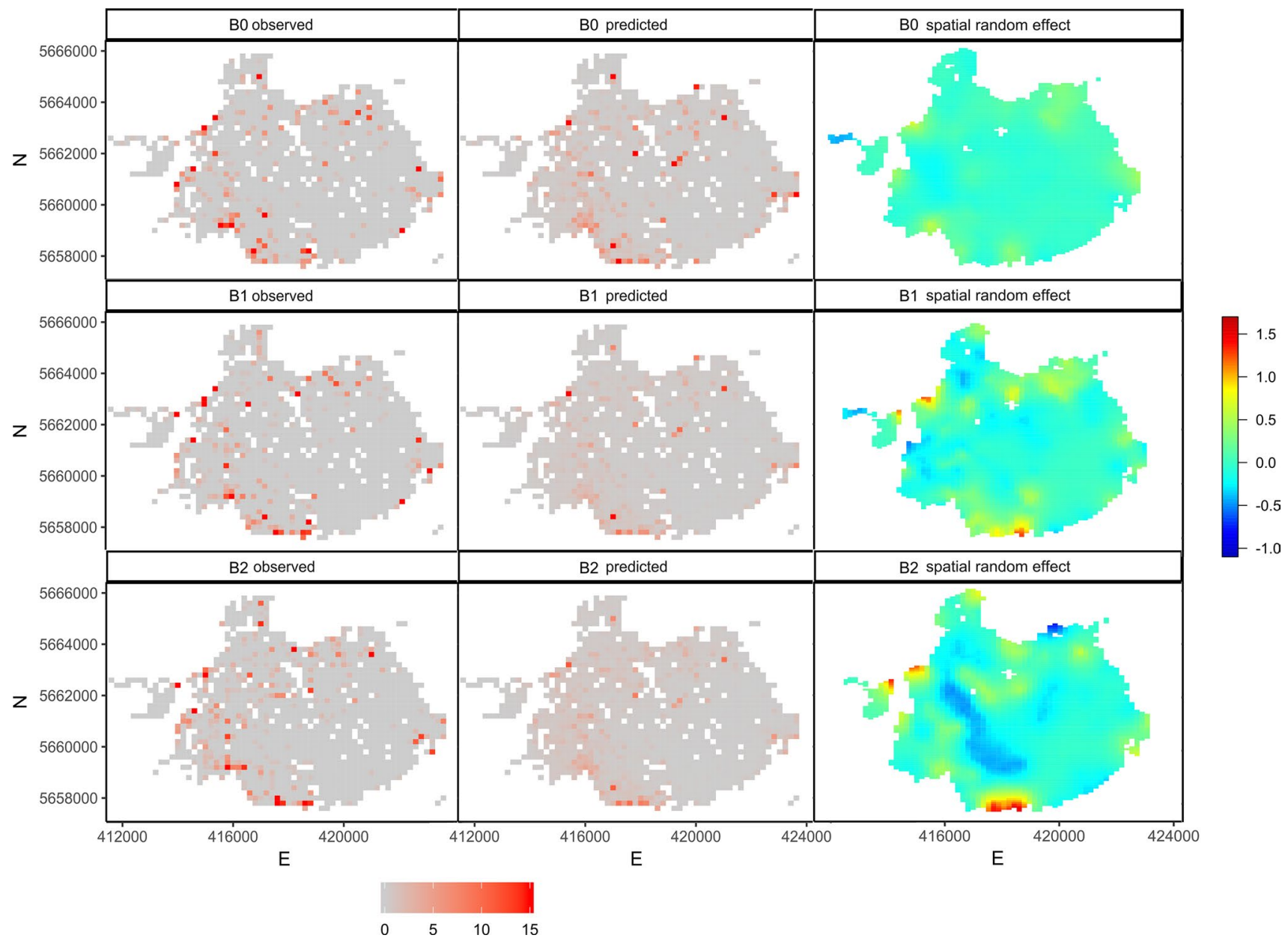

Fig. 6 Example area from within the study region with observed density of beech regeneration (left), spatial prediction of beech regeneration density (middle) and spatial random field for the zero-truncated count part of the ZANB model for the three size classes and part of

early establishment and the date of the inventory, the effect intensities of the explanatory variables employed may not be as strong as in studies with a coordinated examination design, e.g. true experiments. The variables used for our model are all ecologically interpretable. Other studies have used, for example, forest ownership as an explanatory variable for regeneration establishment (Kolo et al. 2017), which has no apparent ecological meaning, or its relevance is obscured. In the following, the fixed effects will be discussed in an ecological context and related to the regeneration cycle of beech (Wagner et al. 2010; Fischer et al. 2016).

\section{Variables influencing the occurrence of beech regeneration}

The occurrence of beech regeneration is influenced by both stand and site characteristics. Due to the short mean seed dispersal distances of beech (Wagner 1999; Millerón the investigation area. Areas shaded dark blue have a lower probability of high regeneration density than predicted by the fixed effects. Yellow to red areas have a higher probability. (Color figure online)

et al. 2013), the occurrence of mature beech in a plot is the primary driver of the occurrence of beech regeneration. As mean dbh offers reliable evidence of fructification (Wagner 1999), the finding that the quadratic mean $\mathrm{dbh}$ of beech influences regeneration occurrence fits. Kolo et al. (2017) arrived at a similar result. They found a positive influence of the mean tree height and the mean age of beeches in the overstorey, which are both closely related to the dbh. A sequence over time can be observed in the explanatory variable as higher levels of beech regeneration are predicted at a larger mean beech dbh. For quadratic mean diameters $>41 \mathrm{~cm}$, the probability of beech regeneration of size class $B 0$ is higher than 0.5 (Fig. 3). In the case of beech regeneration of size class $B 2$, regeneration occurred several years ago and during this time the mature beech trees could grow from 40 to $70 \mathrm{~cm}$ dbh.

However, beech regeneration was also found in plots lacking mature beech trees. Due to the small plot sample 
size, it was not possible to depict seed distribution completely. Spatial patterns of seed availability resulting from the plot environment have only been taken into account in a few studies to date (Shive et al. 2018; Monteiro-Henriques and Fernandes 2018). The model indicated that distance to seed source is another major driver (and limitation) of beech regeneration patterns. This finding was also observed in other studies (Kunstler et al. 2007; Irmscher 2009; Poljanec et al. 2010; Millerón et al. 2013). Poljanec et al. (2010) found that an increase in the distance to the nearest beech stand of $1000 \mathrm{~m}$ reduced beech ingrowth ( $>10 \mathrm{~cm} \mathrm{dbh}$ ) by $46 \%$. Our results also confirmed that the probability of the occurrence of regeneration of size class $B 0$ drops to below 0.5 at a distance of $900 \mathrm{~m}$ (Fig. 3). When modelling established regeneration data, the effective dispersal distance is used. The distances estimated using our model are, therefore, distances for the effective dispersal. These are not to be equated with distance estimates that are based on the primary dispersal, i.e. barochorus seed dispersal (Wagner 1999; Kutter and Gratzer 2006; Sagnard et al. 2007). In the case of effective seed dispersal, the germination and survival of regeneration has to be taken into account. Millerón et al. (2013) showed, for example, that the effective dispersal of beech exceeds the primary dispersal. According to fructification of beech, the age selection of stands $\geq 80$ years for distance determination showed the best fit. The predicted probability of the occurrence of beech of size classes $B 1$ and $B 2$ was smaller than for $B 0$ at the same distance. The different probabilities of occurrence for the different size classes (Fig. 3) contradicted the coefficients, which were estimated to be the same by the model for all size classes (Table 3). The different probabilities in Fig. 3 can be explained by the different total density between the size classes. The threshold of 1 regenerated beech $\{0 ; 1\}$ was reached due to the lower plant density for $B 1$ and $B 2$ at shorter distances. The lower plant density in the larger size classes was a consequence of density-dependent and density-independent mortality with increasing growth (Akashi 1997; Collet and Le Moguedec 2007).

There are two mechanisms for seed dispersal of beech given the two variables in question, namely occurrence of beech in the plot overstorey and distance to the nearest beech stand in the plot environment. While close-range seed dispersal is determined by barochory, zoochorus seed dispersal becomes decisive at distances $\geq 20 \mathrm{~m}$. Compared to the density of seed dispersed barochorusly, the density of seeds dispersed by zoochory is much lower. Millerón et al. (2013) emphasised that zoochorus dispersal takes place on two scales. While small mammals, especially mice, are only able to transport beech nuts over small to medium distances of up to approximately $30 \mathrm{~m}$ (Jensen 1985; Jensen and Nielsen 1986; Den Ouden et al. 2005), birds can move seeds over longer distances (Nilsson 1985). Observed distant dispersal events were probably due to activities of the jay (Garrulus glandarius L.) (Turcek 1961; Nilsson 1985). The nuthatch (Sitta europaea L.) has smaller territories than the jay and usually deposits seed near the seed source and rarely at distances greater than $40 \mathrm{~m}$. Nilsson (1985) observed jays transporting beech nuts about $1 \mathrm{~km}$ from the seed source. Gómez (2003) noted an average distance of $250 \mathrm{~m}$ from the seed source for holm oak acorns (Quercus ilex L.). Jays hide acorns and probably beech nuts in places that are suitable for germination and establishment (Bossema 1979). Although only a small proportion of the beech mast is hidden by the jay, these seeds seem to have a relatively high survival rate (Nilsson 1985). However, Perea et al. (2011) emphasised that for the dispersal of beechnuts by jays, the occurrence of other preferred species, e.g. oaks, and the frequency of nonmasting years should be considered. Nilsson (1985) stated that jays only hide beech nuts when there are no acorns in a particular year. In the case of American beech (Fagus grandifolia EHRH.), dispersal distances of up to $4 \mathrm{~km}$ from the mother tree have been recorded for the blue jay (Cyanocitta cristata L.) (Johnson and Adkisson 1985). The results in relation to the influence of the distance to nearest mature beech stand (D80 in Table 3) may reflect the behaviour of the jay.

A high basal area of spruce in a plot reduces the probability of the occurrence of regeneration of size classes $B 0$ and $B 1$. Beech regeneration in spruce stands is limited by the high stand density, a lack of mother trees and a large distance to neighbouring beech stands. Poljanec et al. (2010) showed that beech ingrowth was not possible in stands featuring a spruce share of $70 \%$.

The negative impact of spruce regeneration density on beech regeneration was an indication of interspecific competition. Existing spruce regeneration of size class $B 2$ prevented establishment of beech seedlings. In contrast, spruce regeneration of size class $B 2$ revealed no effect on beech regeneration of size classes $B 1$ and $B 2$. Investigations by Unkrig (1997), Dobrovolny (2016) and Kühne and Bartsch (2003) examined the influence of irradiation on the composition of beech-spruce regeneration. A higher regeneration density of spruce was associated with higher irradiation due to canopy gaps. Therefore, a higher amount of irradiation can be assumed to promote the establishment of spruce regeneration and, hence, prevent the establishment of beech regeneration.

The effect of site suggests that regeneration is not to be expected on sites that are not favourable for beech. This finding is consistent with the findings of Poljanec et al. (2010). They found a higher probability of beech occurrence on sites with a higher proportion of beech in the potential natural vegetation, which considers soil conditions as well. The absence of beech on hydromorphic sites is an empirical phenomenon that has been observed repeatedly (Ellenberg and 
Leuschner 2010; Aertsen et al. 2012). For the development of an intensive, deep-reaching root system, beech requires loose, well-aerated soil (Asche et al. 1995). In pseudogley soils, it is almost exclusively the fine roots that penetrate the compacted horizons, along shrinkage cracks (Kreutzer 1961). Schmull and Thomas (2000) were able to demonstrate morphological reactions of beech seedlings to waterlogging. Seedlings cannot generate roots below the water table. In addition to morphological reactions, physiological reactions that indicate increased stress in plants can be shown. This finding is consistent with our results. The negative influence of hydromorphic sites increases with increasing size class (Fig. 3).

\section{Variables influencing beech regeneration density}

Taking the ecological characteristics of beech into account, beech regeneration density is highly dependent on the dispersal of beech nuts (Sagnard et al. 2007; Millerón et al. 2013). Most beech nuts fall within the vicinity of the seed tree. According to earlier studies (Poljanec et al. 2010; Klopcic et al. 2012; Ramage and Mangana 2017; Žemaitis et al. 2019), the basal area of beech in a stand significantly influences the density of beech regeneration. A high density of beech regeneration is more likely when the beech basal area in a plot is high. A larger proportion of beech in the plot leads to more beech nuts and, consequently, to more beech regeneration. As beech nuts are highly attractive to seed predators, the rate of predation of beech nuts by small mammals in stands with a low degree of beech admixture could be higher (Kelly and Sork 2002; Yasaka et al. 2003; Kon et al. 2005). The lower beech regeneration density for admixed beech trees can, therefore, result from reduced seed availability and effective predation. In addition to beech basal area, $D_{\mathrm{q}}$ is positively related to beech regeneration density because seed production is related to diameter (Wagner 1999). Furthermore, beech is a late successional species, able to regenerate and establish under a wide range of light conditions (Emborg 1998). This was evidenced by the fact that the size classes $B 0$ and $B 1$ were not dependent on the total basal area. However, there was an optimum relationship between beech basal area and the density of seedlings of size class B0. Different studies have highlighted the weak relationship between regeneration density and light availability (Madsen and Larsen 1997; Szwagrzyk et al. 2001; Petritan et al. 2007; Ammer et al. 2008). Ammer et al. (2008) revealed that the importance of light availability increases with seedling size. All of these results are consistent with the natural regeneration methods commonly used for beech. A shelter provided by mature trees combined with a long regeneration period leads to a high regeneration density (Nyland et al. 2006; Peña et al. 2010).
Although the distance to the nearest mature beech stand had a positive influence on the occurrence of beech regeneration, it did not have any effect on beech regeneration density. Compared to barochorus seed density, the density of zoochorously dispersed seeds was significantly lower. Various investigations of long-distance dispersal of beech seed (Kunstler et al. 2007; Irmscher 2009; Dobrovolny and Tesař 2010; Mirschel et al. 2011) revealed only very low regeneration densities at higher dispersal distances. Therefore, the distance to the nearest mature beech stand influences only occurrence $\{0 ; 1\}$, but not density $\{1, \ldots 15\}$. Kunstler et al. (2007) found an average density of 52 beech seedlings per hectare in pine stands. Dobrovolny and Tesař (2010) observed a density of 65 plants per hectare at a distance of $200 \mathrm{~m}$ from a seed source, while Irmscher (2009) detected 5 beech seedlings per hectare at $240 \mathrm{~m}$ from the nearest seed source. According to our sampling design, a count of 1 beech seedling per plot corresponded to a density of 795 per hectare. As can be seen in Axer and Wagner (2020), higher densities are almost completely absent at greater distances.

Several studies have shown the impact of browsing on regeneration (Ammer 1996; Motta 2003; Boulanger et al. 2009). The results of our study demonstrated that browsing intensity and browsing percentage in rowan had no effect on the occurrence of beech regeneration in this study area, but there was an influence on density. The browsing intensity in rowan was taken as an indication of a certain concentration of game (Chevrier et al. 2012). In contrast to Kamler et al. (2010), who found no correlation between deer density and browsing intensity in rowan, we were able to demonstrate a spatial variation in browsing intensity in rowan, indicating a concentration of game. The overall game density would appear to be decisive for these contrasting findings. Our results reinforced the findings of Klopcic et al. (2012) and Russell et al. (2017). Both of these studies found no impact of browsing on occurrence, but on density. Compared to other tree species, beech is less severely affected by browsing. This makes an absence of beech regeneration due to browsing unlikely (Motta 2003; Götmark et al. 2005; Boulanger et al. 2009). However, density is indirectly influenced by browsing, as the mortality rate of regeneration increases and other plants not preferentially browsed can grow better. Surprisingly, plots with the factor simply browsed rowan exhibited a higher density of beech regeneration of size class $B 0$ than plots with non-browsed rowan. This finding was consistent with the insights obtained by Kupferschmid (2018), who found that browsing of a certain species also depends on the occurrence of other tree species. The occurrence of rowan can lead to a decrease in browsing of beech. In line with our results, Mirschel et al. (2011) also found a positive correlation between browsing intensity and beech regeneration. 
As has been demonstrated, browsing affects regeneration density. According to Kolo et al. (2017), browsing is a major source of error in predicting the probability of regeneration. Therefore, they recommended that browsing intensity be considered in future studies.

\section{Random effects}

Many ecological models take into account spatial autocorrelation in data that is due to biotic and abiotic processes (limited seed dispersal, clumping of safe sites) as well as spatial structure in unobserved explanatory variables (Flores et al. 2009; Bachl et al. 2019). However, the variation of the mean of the random field expresses the variation remaining after taking into account the effects of the covariates (Dutra Silva et al. 2017), i.e. the fixed effects. Our results indicate that the spatial relationship between inventory plots contains information that is not included in the observed covariates, and the inclusion of the spatial random effects improves the overall prediction (Appendix Figure A1, Figure A2, Figure A3). Compared to size classes $B 0$ and $B 1$, $B 2$ exhibited more variation, which cannot be explained by the fixed effects. The long time lag between establishment and inventory in the case of $B 2$ may have contributed to the larger share of variance that is absorbed by the random effects in the model of $B 2$ (Figs. 5,6). Beech regeneration requires almost 20-40 years from germination to reach a dbh of $7 \mathrm{~cm}$ (Hessenmöller et al. 2012). During this time, the environmental conditions that affect growth or mortality can change significantly. Potential seed trees can be harvested. The lack of information on environmental conditions during the establishment phase may lead to a greater proportion of the variability being captured by the random effects. The random effects give insights into unobserved processes. The distribution of spatial random effects can be used as a surrogate to derive processes from spatial patterns (McIntire and Fajardo 2009).

In the north-western part of the example area, the occurrence of beech regeneration was higher than expected based on the fixed effects, while it was lower in the eastern part, as shown in Fig. 5. The pattern suggests that a large-scale process was responsible for this, potentially influenced by the site. Although there was no significant effect of nutrient content on regeneration occurrence, another study found a correlation between site productivity and beech recruitment (Klopcic et al. 2012). Other site variables may have a significant impact and should be tested. In addition to site variables, the suitability of the habitat for seed-dispersing animals and the occurrence of other masting tree species could also affect the probability of the occurrence of beech regeneration and cause the pattern of random effects (Perea et al. 2011; Löf et al. 2018).
A higher regeneration density than that predicted by the fixed effects was found especially at the edges of the forest areas near the city of Dresden. The patterns appeared on a small scale. These areas are visited for recreational use and game may avoid these areas as a result. Mathisen et al. (2018) found that proximity to forest roads affects the intensity of browsing of oak as red deer (Cervus elaphus L.) and roe deer (Capreolus capreolus L.) avoid these areas. A lower local game density can, therefore, lead to a higher regeneration density in the vicinity of cities. Spatial random effects also exhibited a lower density than predicted by the fixed effects in the interior of the forest (Fig. 6). This corresponded to findings of Mathisen et al. (2018) who observed higher browsing intensity in the inner reaches of the forest. In addition to the effect of visitors, real seed sources may not have been included in the data. A comparison of stand inventory databases and remote sensing databases indicated that many individual seed source trees are not recorded in stand databases (Axer and Wagner 2020). Remote sensing data were not available for the whole study area. The small-scale composition of the ground vegetation may also have influenced the regeneration density. The most relevant task for future research is to disentangle all that is pooled together in random effects. Additional variables should be included in the forest inventory for this purpose.

\section{Conclusions}

The natural regeneration and establishment of beech can support the conversion of pure coniferous stands into mixed stands, a task which is relevant to forest management throughout central Europe. The spatial ZANB model, implemented in R-INLA, provides the opportunity to analyse regeneration data. Factors influencing the occurrence and density of beech regeneration can be examined separately. This improves our ecological understanding of the establishment of beech regeneration. At the same time, the study provides information on which additional variables could also have an influence on beech regeneration. The model developed in this study emphasises the variability in regeneration across the study area. The probability of regeneration establishing is dependent on site and overstorey characteristics. However, the most limiting factor for regeneration is seed availability. Due to the very limited dispersal of beech seeds, the position of old beech trees is one of the main drivers of a succession of beech trees into surrounding spruce and pine stands. Knowledge of the location of mother trees and of the distance to the nearest mature beech stand is, therefore, an important source of information for management. Based on this knowledge, natural regeneration can be estimated spatially. Using these predictions, spatial decisions on forest conversion activities can be planned at forest 
management level. Areas in which artificial regeneration is necessary can be identified. At the same time, areas in which there is no need of planting can be identified. The evaluation of the regeneration process, therefore, leads directly to greater control over the effort that must be invested. The model developed in this study can be replicated for other forest districts for which sample points are available. To a large extent, the effects determining seedling occurrence and identified by the model are in alignment with our silvicultural knowledge. The model is also relevant to practitioners, because the variables used in the model were reported in the context of a forest inventory.

Supplementary Information The online version contains supplementary material available at https://doi.org/10.1007/s10342-021-01377-w.

Acknowledgements This work was supported by Staatsbetrieb Sachsenforst. The authors would like to thank Sachsenforst for providing valuable data from their regular forest inventory. We are especially grateful to Dirk-Roger Eisenhauer for the constructive cooperation. We thank Dominik Flatten and David Butler Manning for proofreading the text. We would also like to thank Havard Rue and Elias Krainski for the detailed information about their package. Our thanks also to the anonymous reviewers for their useful suggestions.

Funding Open Access funding enabled and organized by Projekt DEAL. The work was supported financially by Staatsbetrieb Sachsenforst.

Availability of data and materials The datasets analysed during the study are not publicly available as the data are highly sensitive proprietary data of the state forest enterprise.

\section{Declarations}

Conflict of interest The authors declare that they have no conflict of interest.

Open Access This article is licensed under a Creative Commons Attribution 4.0 International License, which permits use, sharing, adaptation, distribution and reproduction in any medium or format, as long as you give appropriate credit to the original author(s) and the source, provide a link to the Creative Commons licence, and indicate if changes were made. The images or other third party material in this article are included in the article's Creative Commons licence, unless indicated otherwise in a credit line to the material. If material is not included in the article's Creative Commons licence and your intended use is not permitted by statutory regulation or exceeds the permitted use, you will need to obtain permission directly from the copyright holder. To view a copy of this licence, visit http://creativecommons.org/licenses/by/4.0/.

\section{References}

Aertsen W, Kint V, de Vos B, Deckers J, van Orshoven J, Muys B (2012) Predicting forest site productivity in temperate lowland from forest floor, soil and litterfall characteristics using boosted regression trees. Plant Soil 354:157-172. https://doi.org/10.1007/ s11104-011-1052-z
Akashi N (1997) Dispersion pattern and mortality of seeds and seedlings of Fagus crenata Blume in a cool temperate forest in western Japan. Ecol Res 12:159-165. https://doi.org/10.1007/BF025 23781

Ammer C (1996) Impact of ungulates on structure and dynamics of natural regeneration of mixed mountain forests in the Bavarian Alps. For Ecol Manag 88:43-53. https://doi.org/10.1016/S03781127(96)03808-X

Ammer C, Stimm B, Mosandl R (2008) Ontogenetic variation in the relative influence of light and belowground resources on European beech seedling growth. Tree Physiol 28:721-728. https:// doi.org/10.1093/treephys/28.5.721

Arab A (2015) Spatial and spatio-temporal models for modeling epidemiological data with excess zeros. Int J Environ Res Public Health 12:10536-10548. https://doi.org/10.3390/ijerph1209 10536

Asche N, Thombansen K, Becker A (1995) Untersuchungen zur Wurzelverteilung unterschiedlich belaubter Buchen-Eine Fallstudie. Forstwissenschaftliches Centralblatt vereinigt mit Tharandter forstliches Jahrbuch 114:340-347

Axer M, Wagner S (2020) Methodical approaches for modelling the long-distance dispersal of European beech from inventory data at forest management level: potential density of beech regeneration depending on the distance to the potential seed trees. Allgemeine Forst und Jagdzeitung 190(9/10):222-236. https:// doi.org/10.23765/afjz0002049

Bachl FE, Lindgren F, Borchers DL, Illian JB (2019) inlabru: an R package for Bayesian spatial modelling from ecological survey data. Methods Ecol Evol 10:760-766. https://doi.org/10.1111/ 2041-210X.13168

Beguin J, Martino S, Rue H, Cumming SG (2012) Hierarchical analysis of spatially autocorrelated ecological data using integrated nested Laplace approximation. Methods Ecol Evol 3:921-929. https://doi.org/10.1111/j.2041-210X.2012.00211.x

Bivand R, Rundel C (2019) rgeos: interface to Geometry EngineOpen Source ('GEOS'). https://CRAN.R-project.org/package $=$ rgeos

Blangiardo M, Finazzi F, Cameletti M (2016) Two-stage Bayesian model to evaluate the effect of air pollution on chronic respiratory diseases using drug prescriptions. Spatial Spatio-temporal Epidemiol 18:1-12. https://doi.org/10.1016/j.sste.2016.03.001

Bossema I (1979) Jays and oaks: an eco-ethological study of a symbiosis. Behaviour 70:1-116

Boulanger V, Baltzinger C, Said S, Ballon P, Picard J-F, Dupouey J-L (2009) Ranking temperate woody species along a gradient of browsing by deer. For Ecol Manag 258:1397-1406. https:// doi.org/10.1016/j.foreco.2009.06.055

Brown JMB (1953) Studies on British beechwoods, 20th edn. Forestry Commission Bulletin, London

Cameletti M, Lindgren F, Simpson D, Rue H (2013) Spatio-temporal modeling of particulate matter concentration through the SPDE approach. AStA Adv Stat Anal 97:109-131. https://doi.org/10. 1007/s10182-012-0196-3

Chevrier T, Said S, Widmer O, Hamard J-P, Saint-Andrieux C, Gaillard J-M (2012) The oak browsing index correlates linearly with roe deer density: a new indicator for deer management? Eur J Wildl Res 58:17-22. https://doi.org/10.1007/ s10344-011-0535-9

Clark JS, Silman M, Kern R et al (1999) Seed dispersal near and far: patterns across temperate and tropical forests. Ecology 80:1475-1494. https://doi.org/10.1890/0012-9658(1999) 080[1475:SDNAFP]2.0.CO;2

Coll L, Balandier P, Picon-Cochard C, Prévosto B, Curt T (2003) Competition for water between beech seedlings and surrounding vegetation in different light and vegetation composition 
conditions. Ann For Sci 60:593-600. https://doi.org/10.1051/ forest:2003051

Coll L, Balandier P, Picon-Cochard C (2004) Morphological and physiological responses of beech (Fagus sylvatica) seedlings to grass-induced belowground competition. Tree Physiol 24:45-54. https://doi.org/10.1093/treephys/24.1.45

Collet C, Le Moguedec G (2007) Individual seedling mortality as a function of size, growth and competition in naturally regenerated beech seedlings. Forestry 80:359-370. https://doi.org/10.1093/ forestry/cpm016

Cunningham RB, Lindenmayer DB (2005) Modeling count data of rare species: some statistical issues. Ecology 86:1135-1142. https:// doi.org/10.1890/04-0589

Den Ouden J, Jansen PA, Smit R (2005) Jays, mice and oaks: predation and dispersal of Quercus robur and Q. petraea in North-western Europe. In: Seed fate. Predation, dispersal and seedling establishment, pp 223-240

Dobrovolny L (2016) Density and spatial distribution of beech (Fagus sylvatica L.) regeneration in Norway spruce (Picea abies (L.) Karsten) stands in the central part of the Czech Republic. iForest Biogeosci For 9:666-672. https://doi.org/10.3832/ifor1581-008

Dobrovolny L, Tesař V (2010) Extent and distribution of beech (Fagus sylvatica $\mathrm{L}$ ) regeneration by adult trees individually dispersed over a spruce monoculture. J For Sci 56:589-599. https://doi. org/10.17221/12/2010-JFS

Dobrowolska D (2006) Oak natural regeneration and conversion processes in mixed Scots pine stands. Forestry 79:503-513. https:// doi.org/10.1093/forestry/cp1034

Dobrowski SZ, Swanson AK, Abatzoglou JT, Holden ZA, Safford HD, Schwartz MK, Gavin DG (2015) Forest structure and species traits mediate projected recruitment declines in western US tree species. Glob Ecol Biogeogr 24:917-927. https://doi.org/10. 1111/geb.12302

Dutra Silva L, Brito de Azevedo E, Bento Elias R, Silva L (2017) Species distribution modeling: comparison of fixed and mixed effects models using INLA. ISPRS Int J Geo Inf 6:391-426. https://doi. org/10.3390/ijgi6120391

Ellenberg H, Leuschner C (2010) Vegetation Mitteleuropas mit den Alpen in ökologischer, dynamischer und historischer Sicht; 203 Tabellen, 6th edn. Ulmer, Stuttgart

Emborg J (1998) Understorey light conditions and regeneration with respect to the structural dynamics of a near-natural temperate deciduous forest in Denmark. For Ecol Manag 106:83-95. https://doi.org/10.1016/S0378-1127(97)00299-5

Entezari R, Brown PE, Rosenthal JS (2019) Bayesian spatial analysis of hardwood tree counts in forests via MCMC. Environmetrics. https://doi.org/10.1002/env.2608

Felton A, Nilsson U, Sonesson J, Felton AM, Roberge J-M, Ranius T, Ahlström M, Bergh J, Björkman C, Boberg J et al (2016) Replacing monocultures with mixed-species stands: ecosystem service implications of two production forest alternatives in Sweden. Ambio 45:124-139. https://doi.org/10.1007/s13280-015-0749-2

Fischer H, Huth F, Hagemann U, Wagner S (2016) Developing restoration strategies for temperate forests using natural regeneration processes. In: Stanturf JA (ed) Restoration of boreal and temperate forests. CRC Press, Boca Raton, pp 103-164

Finkeldey R, Hattemer HH (2010) Genetische Variation in Wäldernwo stehen wir? Forstarchiv 81:123-129. https://doi.org/10.2376/ 0300-4112-81-123

Flores O, Rossi V, Mortier F (2009) Autocorrelation offsets zeroinflation in models of tropical saplings density. Ecol Model 220:1797-1809. https://doi.org/10.1016/j.ecolmodel.2009.01. 030

Fortin M, DeBlois J (2007) Modeling tree recruitment with zeroinflated models: the example of hardwood stands in southern
Québec, Canada. For Sci 53:529-539. https://doi.org/10.1093/ forestscience/53.4.529

Fuglstad G-A, Beguin J (2018) Environmental mapping using Bayesian spatial modelling (INLA/SPDE): A reply to Huang et al. (2017). Science Total Environ 624:596-598. https://doi.org/10.1016/j. scitotenv.2017.12.067

Gauer J, Aldinger E (2005) Forest ecological growth districts of Germany. Waldökologische Naturräume Deutschlands: forstliche Wuchsgebiete und Wuchsbezirke; mit Karte 1: 1.000. 000. Verein für Forstliche Standortkunde und Forstpflanzenzüchtung

Gauer J, Kroiher F (2012) Waldökologische Naturräume Deutschlands. Forstliche Wuchsgebiete und Wuchsbezirke. Digitale Topographische Grundlagen - Neubearbeitung Stand 2011. Johann Heinrich von Thünen-Institut

Gelman A, Hwang J, Vehtari A (2014) Understanding predictive information criteria for Bayesian models. Stat Comput 24:997-1016. https://doi.org/10.1007/s11222-013-9416-2

Gómez JM (2003) Spatial patterns in long-distance dispersal of Quercus ilex acorns by jays in a heterogeneous landscape. Ecography 26:573-584. https://doi.org/10.1034/j.1600-0587. 2003.03586.x

Götmark F, Berglund Å, Wiklander K (2005) Browsing damage on broadleaved trees in semi-natural temperate forest in Sweden, with a focus on oak regeneration. Scand J For Res 20:223-234. https://doi.org/10.1080/02827580510008383

Gräler B, Pebesma E, Heuvelink G (2016) Spatio-temporal interpolation using gstat. R Journal 8:204-218

Harper JL (2010) Population biology of plants. The Blackburn Press, London

Hessenmöller D, Fritzlar D, Schulze E-D (2012) Die Buchenplenterwälder in Thüringen. AFZ-DerWald 12:18-21

Irmscher T (2009) Zoochores Ausbreitungspotenzial der Rotbuche (Fagus sylvatica 1.) mit Blick auf die Minimierung der Eingriffsintensität beim Waldumbau in Wäldern mit Naturschutzstatus. Forstarchiv 80:29-32

Jensen TS (1985) Seed-seed predator interactions of European beech, Fagus silvatica and forest rodents, Clethrionomys glareolus and Apodemus flavicollis. Oikos 44:149-156. https://doi.org/10.2307/ 3544056

Jensen TS, Nielsen OF (1986) Rodents as seed dispersers in a heathoak wood succession. Oecologia 70:214-221. https://doi.org/10. 1007/BF00379242

Johnson WC, Adkisson CS (1985) Dispersal of beech nuts by blue jays in fragmented landscapes. Am Midl Nat 113:319-324. https:// doi.org/10.2307/2425577

Kaliszewski A (2017) Cost analysis of artificial and natural oak regeneration in selected forest districts. For Res Pap 78:315-321. https://doi.org/10.1515/frp-2017-0035

Kamler J, Homolka M, Barančeková M, Krojerová-Prokešová J (2010) Reduction of herbivore density as a tool for reduction of herbivore browsing on palatable tree species. Eur J For Res 129:155162. https://doi.org/10.1007/s10342-009-0309-z

Kelly D, Sork VL (2002) Mast seeding in perennial plants: why, how, where? Annu Rev Ecol Syst 33:427-447. https://doi.org/10.1146/ annurev.ecolsys.33.020602.095433

Klopcic M, Poljanec A, Boncina A (2012) Modelling natural recruitment of European beech (Fagus sylvatica L.). For Ecol Manag 284:142-151. https://doi.org/10.1016/j.foreco.2012.07.049

Klopčič M, Simončič T, Bončina A (2015) Comparison of regeneration and recruitment of shade-tolerant and light-demanding tree species in mixed uneven-aged forests: experiences from the Dinaric region. Forestry Int J For Res 88:552-563. https://doi.org/10. 1093/forestry/cpv021 
Kolo H, Ankerst D, Knoke T (2017) Predicting natural forest regeneration: a statistical model based on inventory data. Eur J For Res 136:923-938. https://doi.org/10.1007/s10342-017-1080-1

Kon H, Noda T, Terazawa K, Koyama H, Yasaka M (2005) Evolutionary advantages of mast seeding in Fagus crenata. J Ecol 93:1148-1155. https://doi.org/10.1111/j.1365-2745.2005. 01040.x

Krainski ET, Gómez-Rubio V, Bakka H, Lenzi A, Castro-Camilo D, Simpson D, Lindgren F, Rue H (2019) Advanced spatial modeling with stochastic partial differential equations using $\mathrm{R}$ and INLA. CRC Press, Boca Raton

Kreutzer K (1961) Wurzelbildung junger Waldbäume auf Pseudogleyböden. Forstwissenschaftliches Centralblatt 80:356-392

Kühne C, Bartsch N (2003) Zur Naturverjungung von Fichten-BuchenMischbestanden im Solling. Forst und Holz 58:3-7

Kunstler G, Thuiller W, Curt T, Bouchaud M, Jouvie R, Deruette F, Lepart J (2007) Fagus sylvatica L. recruitment across a fragmented Mediterranean Landscape, importance of long distance effective dispersal, abiotic conditions and biotic interactions. Divers Distrib 13:799-807. https://doi.org/10.1111/j.1472-4642. 2007.00404.x

Kupferschmid AD (2018) Selective browsing behaviour of ungulates influences the growth of Abies alba differently depending on forest type. For Ecol Manag 429:317-326. https://doi.org/10.1016/j. foreco.2018.06.046

Kutter M, Gratzer G (2006) New methods for estimating seed dispersal distances of forest trees on the example of the spread of Picea abies, Abies alba and Fagus sylvatica. Centralblatt für das gesamte Forstwesen 123:103-120

Leach K, Montgomery WI, Reid N (2016) Modelling the influence of biotic factors on species distribution patterns. Ecol Model 337:96-106. https://doi.org/10.1016/j.ecolmodel.2016.06.008

Lexerod N, Eid T (2005) Recruitment models for Norway spruce, Scots pine, birch and other broadleaves in young growth forests in Norway. Silva Fennica 39:391-406

Li R, Weiskittel AR, Kershaw JA Jr (2011) Modeling annualized occurrence, frequency, and composition of ingrowth using mixedeffects zero-inflated models and permanent plots in the Acadian Forest Region of North America. Can J For Res 41:2077-2089. https://doi.org/10.1139/x11-117

Lin N, Bartsch N, Vor T (2014) Long-term effects of gap creation and liming on understory vegetation with a focus on tree regeneration in a European beech (Fagus sylvatica $\mathrm{L}$ ) forest. Ann For Res 57:233-246. https://doi.org/10.15287/afr.2014.274

Lindgren F, Rue H (2015) Bayesian spatial modelling with R-INLA. J Stat Softw 63:1-25. https://doi.org/10.18637/jss.v063.i19

Löf M, Ammer C, Coll L, Drössler L, Huth F, Madsen P, Wagner S (2018) Regeneration patterns in mixed-species stands. In: Dynamics, silviculture and management of mixed forests. Springer, pp 103-130

Madsen P (1994) Growth and survival of Fagus sylvatica seedlings in relation to light intensity and soil water content. Scand J For Res 9:316-322. https://doi.org/10.1080/02827589409382846

Madsen P (1995) Effects of seedbed type on wintering of beech nuts (Fagus sylvatica) and deer impact on sprouting seedlings in natural regeneration. For Ecol Manag 73:37-43. https://doi.org/10. 1016/0378-1127(94)03503-O

Madsen P, Larsen JB (1997) Natural regeneration of beech (Fagus sylvatica L.) with respect to canopy density, soil moisture and soil carbon content. For Ecol Manag 97:95-105. https://doi.org/ 10.1016/S0378-1127(97)00091-1

Manso R, Ligot G, Fortin M (2019) A recruitment model for beech-oak pure and mixed stands in Belgium. Forestry 93:124-132. https:// doi.org/10.1093/foresj/cpz056
Mathisen MK, Wójcicki A, Borowski Z (2018) Effects of forest roads on oak trees via cervid habitat use and browsing. For Ecol Manag 424:378-386. https://doi.org/10.1016/j.foreco.2018.04.057

McIntire EJ, Fajardo A (2009) Beyond description: the active and effective way to infer processes from spatial patterns. Ecology 90:46-56. https://doi.org/10.1890/07-2096.1

Miina J, Eerikäinen K, Hasenauer H (2006) Modelling forest regeneration. In: Hasenauer $\mathrm{H}$ (ed) Sustainable forest management: growth models for Europe. Springer, pp 93-109

Milad M, Schaich H, Konold W (2013) How is adaptation to climate change reflected in current practice of forest management and conservation? A case study from Germany. Biodivers Conserv 22:1181-1202. https://doi.org/10.1007/s10531-012-0337-8

Millerón M, Lopez de Heredia U, Lorenzo Z, Alonso J, Dounavi A, Gil L, Nanos N (2013) Assessment of spatial discordance of primary and effective seed dispersal of European beech (Fagus sylvatica L.) by ecological and genetic methods. Mol Ecol 22:1531-1545. https://doi.org/10.1111/mec. 12200

Minotta G, Pinzauti S (1996) Effects of light and soil fertility on growth, leaf chlorophyll content and nutrient use efficiency of beech (Fagus sylvatica L.) seedlings. For Ecol Manag 86:61-71. https://doi.org/10.1016/S0378-1127(96)03796-6

Mirschel F, Zerbe S, Jansen F (2011) Driving factors for natural tree rejuvenation in anthropogenic pine (Pinus sylvestris L.) forests of NE Germany. For Ecol Manag 261:683-694. https://doi.org/ 10.1016/j.foreco.2010.11.025

Monteiro-Henriques T, Fernandes P (2018) Regeneration of native forest species in mainland Portugal: Identifying main drivers. Forests 9:694-716. https://doi.org/10.3390/f9110694

Motta R (2003) Ungulate impact on rowan (Sorbus aucuparia L.) and Norway spruce (Picea abies (L.) Karst.) height structure in mountain forests in the eastern Italian Alps. For Ecol Manag 181:139-150. https://doi.org/10.1016/S0378-1127(03)00128-2

Musenge E, Chirwa TF, Kahn K, Vounatsou P (2013) Bayesian analysis of zero inflated spatiotemporal HIV/TB child mortality data through the INLA and SPDE approaches: applied to data observed between 1992 and 2010 in rural North East South Africa. Int J Appl Earth Obs Geoinf 22:86-98. https://doi.org/ 10.1016/j.jag.2012.04.001

Nathan R, Muller-Landau HC (2000) Spatial patterns of seed dispersal, their determinants and consequences for recruitment. Trends Ecol Evol 15:278-285. https://doi.org/10.1016/S01695347(00)01874-7

Nilsson SG (1985) Ecological and evolutionary interactions between reproduction of beech Fagus silvatica and seed eating animals. Oikos 44:157-164. https://doi.org/10.2307/3544056

Nyland RD, Bashant AL, Bohn KK, Verostek JM (2006) Interference to hardwood regeneration in northeastern North America: controlling effects of American beech, striped maple, and hobblebush. North J Appl For 23:122-132. https://doi.org/10.1093/ njaf/23.2.122

Oddou-Muratorio S, Klein EK, Vendramin GG et al (2011) Spatial vs. temporal effects on demographic and genetic structures: the roles of dispersal, masting and differential mortality on patterns of recruitment in Fagus sylvatica. Mol Ecol 20:19972010. https://doi.org/10.1111/j.1365-294X.2011.05039.x

Olesen CR, Madsen P (2008) The impact of roe deer (Capreolus capreolus), seedbed, light and seed fall on natural beech (Fagus sylvatica) regeneration. For Ecol Manag 255:39623972. https://doi.org/10.1016/j.foreco.2008.03.050

Övergaard R, Gemmel P, Karlsson M (2007) Effects of weather conditions on mast year frequency in beech (Fagus sylvatica L.) in Sweden. Forestry 80:555-565. https://doi.org/10.1093/fores try/cpm020

Owens JN, Blake MD (1985) Forest tree seed production. A review of the literature and recommendations for future research, 53rd 
edn. Information Report - Petawawa National Forestry Institute, Canadian Forestry Service

Paluch J, Bartkowicz L, Moser WK (2019) Interspecific effects between overstorey and regeneration in small-scale mixtures of three late-successional species in the Western Carpathians (southern Poland). Eur J For Res 138:889-905. https://doi.org/ 10.1007/s 10342-019-01209-y

Peña JFB, Remeš J, Bílek L (2010) Dynamics of natural regeneration of even-aged beech (Fagus sylvatica $\mathrm{L}$ ) stands at different shelterwood densities. J For Sci 56:580-588. https://doi.org/ 10.17221/69/2010-JFS

Perea R, San Miguel A, Gil L (2011) Flying vs. climbing: factors controlling arboreal seed removal in oak-beech forests. For Ecol Manag 262:1251-1257. https://doi.org/10.1016/j.foreco. 2011.06.022

Petritan AM, von Lupke B, Petritan IC (2007) Effects of shade on growth and mortality of maple (Acer pseudoplatanus), ash (Fraxinus excelsior) and beech (Fagus sylvatica) saplings. Forestry 80:397-412. https://doi.org/10.1093/forestry/cpm030

Poljanec A, Ficko A, Boncina A (2010) Spatiotemporal dynamic of European beech (Fagus sylvatica L.) in Slovenia, 1970-2005. For Ecol Manag 259:2183-2190. https://doi.org/10.1016/j. foreco.2009.09.022

Polley H, Hennig P, Kroiher F, Marks A, Riedel T, Schmidt U, Schwitzgebel F, Stauber T (2018) Der Wald in Deutschland: Ausgewählte Ergebnisse der dritten Bundeswaldinventur, 3rd edn

Qin Y (1998) Ingrowth models and juvenile mixed wood stand dynamics. Master Thesis, University of Alberta

R Core Team (2018) R: a language and environment for statistical computing, Vienna, Austria. https://www.R-project.org/

Ramage BS, Mangana IJ (2017) Conspecific negative density dependence in American beech. For Ecosyst 4:8. https://doi.org/10. 1186/s40663-017-0094-y

Rathbun SL, Fei S (2006) A spatial zero-inflated Poisson regression model for oak regeneration. Environ Ecol Stat 13:409. https:// doi.org/10.1007/s10651-006-0020-x

Ribbens E, Silander JA Jr, Pacala SW (1994) Seedling recruitment in forests: calibrating models to predict patterns of tree seedling dispersion. Ecology 75:1794-1806. https://doi.org/10.2307/ 1939638

Rue H, Martino S, Chopin N (2009) Approximate Bayesian inference for latent Gaussian models by using integrated nested Laplace approximations. J R Stat Soc Ser B (Stat Methodol) 71:319-392. https://doi.org/10.1111/j.1467-9868.2008.00700.x

Runkle JR (1989) Synchrony of regeneration, gaps, and latitudinal differences in tree species diversity. Ecology 70:546-547. https:// doi.org/10.2307/1940199

Russell MB, Westfall JA, Woodall CW (2017) Modeling browse impacts on sapling and tree recruitment across forests in the northern United States. Can J For Res 47:1474-1481. https:// doi.org/10.1139/cjfr-2017-0155

Sadykova D, Scott BE, de Dominicis M, Wakelin SL, Sadykov A, Wolf J (2017) Bayesian joint models with INLA exploring marine mobile predator-prey and competitor species habitat overlap. Ecol Evol 7:5212-5226. https://doi.org/10.1002/ece3.3081

Sagnard F, Pichot C, Dreyfus P, Jordano P, Fady B (2007) Modelling seed dispersal to predict seedling recruitment: recolonization dynamics in a plantation forest. Ecol Model 203:464-474. https://doi.org/10.1016/j.ecolmodel.2006.12.008

Schmull M, Thomas FM (2000) Morphological and physiological reactions of young deciduous trees (Quercus robur L., Q. petraea [Matt.] Liebl., Fagus sylvatica L.) to waterlogging. Plant Soil 225:227-242. https://doi.org/10.1023/A:1026516027096

Schweiger J, Sterba H (1997) A model describing natural regeneration recruitment of Norway spruce (Picea abies (L.) Karst.) in
Austria. For Ecol Manag 97:107-118. https://doi.org/10.1016/ S0378-1127(97)00092-3

Shen C, Nelson AS (2018) Natural conifer regeneration patterns in temperate forests across the Inland Northwest, USA. Ann For Sci 75:54. https://doi.org/10.1007/s13595-018-0724-8

Shive KL, Preisler HK, Welch KR, Safford HD, Butz RJ, O'Hara KL, Stephens SL (2018) From the stand scale to the landscape scale: predicting the spatial patterns of forest regeneration after disturbance. Ecol Appl 28:1626-1639. https://doi.org/10.1002/eap. 1756

Sterba H, Golser M, Schweiger J, Hasenauer H (1997) Modelle für das Ankommen und das Wachstum der Naturverjüngung. Centralblatt für das gesamte Forstwesen 114:11-33

Szwagrzyk J, Szewczyk J, Bodziarczyk J (2001) Dynamics of seedling banks in beech forest: results of a 10-year study on germination, growth and survival. For Ecol Manag 141:237-250. https://doi. org/10.1016/S0378-1127(00)00332-7

Turcek FJ (1961) Ökologische Beziehungen der Vögel und Gehölze. Verlag der Slowakischen Akademie der Wissenschaften, Bratislava

Unkrig V (1997) Zur Verjüngung von Buche und Fichte im Naturwald Sonnenkopf. Forst und Holz 52:538-543

Vanclay JK (1992) Modelling regeneration and recruitment in a tropical rain forest. Can J For Res 22:1235-1248. https://doi.org/10. 1139/x92-165

Vrška T, Ponikelský J, Pavlicová P, Janík D, Adam D (2016) Twenty years of conversion: from Scots pine plantations to oak dominated multifunctional forests. iForest-Biogeosci For 10:75. https://doi.org/10.3832/ifor1967-009

Wagner S (1999) The initial phase of natural regeneration in mixed ash-beech stands-ecological aspects. Sauerländer

Wagner S, Collet C, Madsen P, Nakashizuka T, Nyland RD, SaghebTalebi K (2010) Beech regeneration research: from ecological to silvicultural aspects. For Ecol Manag 259:2172-2182. https:// doi.org/10.1016/j.foreco.2010.02.029

Welch KR, Safford HD, Young TP (2016) Predicting conifer establishment post wildfire in mixed conifer forests of the North American Mediterranean-climate zone. Ecosphere. https://doi.org/10. $1002 /$ ecs 2.1609

Welsh AH, Cunningham RB, Donnelly CF, Lindenmayer DB (1996) Modelling the abundance of rare species: statistical models for counts with extra zeros. Ecol Model 88:297-308. https://doi.org/ 10.1016/0304-3800(95)00113-1

Wikberg P-E (2004) Occurrence, morphology and growth of understory saplings in Swedish forests. Doctoral thesis, Acta Universitatis Agriculturae Sueciae

Wild J, Kopecký M, Svoboda M, Zenáhlíková J, Edwards-Jonášová M, Herben T (2014) Spatial patterns with memory: tree regeneration after stand-replacing disturbance in Picea abies mountain forests. J Veg Sci 25:1327-1340. https://doi.org/10.1111/jvs.12189

Yang Y, Huang S (2015) Two-stage ingrowth models for four major tree species in Alberta. Eur J For Res 134:991-1004. https://doi. org/10.1007/s10342-015-0904-0

Yasaka M, Terazawa K, Koyama H, Kon H (2003) Masting behavior of Fagus crenata in northern Japan: spatial synchrony and predispersal seed predation. For Ecol Manag 184:277-284. https:// doi.org/10.1016/S0378-1127(03)00157-9

Zell J, Rohner B, Thürig E, Stadelmann G (2019) Modeling ingrowth for empirical forest prediction systems. For Ecol Manag 433:771-779. https://doi.org/10.1016/j.foreco.2018.11.052

Žemaitis P, Gil W, Borowski Z (2019) Importance of stand structure and neighborhood in European beech regeneration. For Ecol Manag 448:57-66. https://doi.org/10.1016/j.foreco.2019.05.066

Zerbe S (2002) Restoration of natural broad-leaved woodland in Central Europe on sites with coniferous forest plantations. For Ecol 
Manag 167:27-42. https://doi.org/10.1016/S0378-1127(01) 00686-7

Zhang X, Lei Y, Cai D, Liu F (2012) Predicting tree recruitment with negative binomial mixture models. For Ecol Manag 270:209215. https://doi.org/10.1016/j.foreco.2012.01.028

Zuur AF, Ieno EN, Walker NJ, Saveliev AA, Smith GM (2009) Mixed effects models and extensions in ecology with R. Gail M, Krickeberg K, Samet JM, Tsiatis A, Wong W, editors. Spring Science and Business Media, New York

Zuur AF, Ieno EN, Elphick CS (2010) A protocol for data exploration to avoid common statistical problems. Methods Ecol Evol 1:3-14. https://doi.org/10.1111/j.2041-210X.2009.00001.x
Zuur AF, Ieno EN, Saveliev AA (2017) Beginner's guide to spatial, temporal and spatial-temporal ecological data analysis with R-INLA. Highland Statistics Ltd, Newburgh

Zuur AF, Ieno EN, Saveliev AA (2018) Beginner's guide to spatial, temporal and spatial-temporal ecological data analysis with R-INLA. Highland Statistics Ltd, Newburgh

Publisher's Note Springer Nature remains neutral with regard to jurisdictional claims in published maps and institutional affiliations. 